\title{
PREVARICACIONES URBANÍSTICAS DEL ART.320 CP: PROBLEMAS LEGISLATIVOS NO RESUELTOS Y DIFICULTADES APLICATIVAS, EN LA PRÁCTICA RECIENTE
}

\author{
Elena M. Górriz Royo*
}

Resumen: Los delitos de prevaricación urbanística fueron reformados en 2010 si bien, en este trabajo se analiza si las modificaciones introducidas fueron eficaces para perseguir esta clase de corrupción. Para ello se estudia el art. $320 \mathrm{CP}$ en sus dos apartados, analizando, en particular, las novedosas modalidades omisivas del apartado $1^{\circ} \mathrm{y}$, asimismo, los delitos del apartado $2^{\circ}$. En especial, se destacan los problemas que aún siguen planteando aquellos delitos, proponiendo concretas mejoras en su redacción con el fin de orientar su aplicación solo a los casos más graves.

Palabras clave: corrupción urbanística, prevaricaciones urbanísticas, funcionarios públicos, inspector urbanístico, autoridades, licencias e instrumentos del planeamiento.

Recibido: septiembre 2017. Aceptado: junio 2018

* Profesora Titular de Derecho Penal. ORCID ID: 0000-0002-2852-9446

Departamento de Derecho penal. Facultad de Derecho. Universitat de València. Avda. Tarongers, s/n. 46.022 Valencia. Email: elena.gorriz@uv.es. 


\title{
CORRUPTION CONCERNING THE ORGANIZATION \\ OF THE TERRITORY OF THE ART. 320 CP: LEGISLATIVE NOT \\ DECISIVE PROBLEMS AND APPLICATIVE DIFFICULTIES, \\ IN THE RECENT PRACTICE
}

\begin{abstract}
Crimes of corruption concerning the organization of the territory and town planning were reformed in 2010. However, in this paper, it is analyzed whether or not, those shifts were efficient in order to prosecute that kind of corruption. With this aim, this work studies the two paragraphs of the article 320 of the Spanish Penal Code. Specially focuses the attention in the new offences of omission of the paragraph $1^{\circ}$ and, additionally, in the offence of paragraph $2^{\circ}$. Particularly, this research underlines the legal problems which still arise in regard with these offences and proposes specific changes in the article $320 \mathrm{CP}$ in order to apply them only in cases of the gravest wrongdoings.
\end{abstract}

Keywords: corruption concerning the organization of the territory, perverting the town planning Administration, civil servants, urban inspector, authorities, licenses and instruments of planning.

\section{El punto de partida: la corrupción urbanística a la luz del contexto criminológico reciente}

Los delitos de prevaricación urbanística siguen ocupando un modesto lugar en la aplicación práctica reciente de los delitos contra la Administración pública. En contraste con la realidad criminológica, son unos delitos que no han atraído la atención del legislador penal en las últimas reformas, pues no se encuentran entre el nutrido grupo de figuras delictivas afectadas por la LO 1/2015, de 30 de marzo. Y ello a pesar de que, como se indicará después, aquella reforma penal introdujo algún cambio de calado en otros preceptos del Capítulo I, Título XVI donde se alojan los delitos contra la Ordenación del Territorio, concretamente en el apartado $3^{\circ}$ del art.319 CP. La redacción vigente de las prevaricaciones urbanísticas, así como las consecuencias jurídicas que tienen previstas, proceden de la reforma acometida a través de $L O 5 / 2010$, de 22 de junio (BOE n ${ }^{\circ} 152$, de 23 de 
junio) que será objeto de análisis en el presente trabajo, tratando de reparar, asimismo, en su repercusión en la práctica judicial reciente. Porque lo cierto es que, a pesar de aquella reforma, la eficacia de la regulación prevista en el art.320 CP puede ponerse en entredicho, sobre todo por lo que respecta a los delitos de su apartado 2, con más frecuencia cometidos por autoridades.

Esta reflexión contrasta con la realidad criminológica reciente de nuestro país, en donde, hasta el año 2010, el urbanismo era el ámbito donde se concentraba, mayoritariamente, la corrupción conocida en España. ${ }^{1}$ De hecho, fueron muchos los casos que, procedentes de la llamada "década prodigiosa" del urbanismo $^{2}$-propia de finales del s. XX-, fueron enjuiciados a principios de este siglo, pudiendo destacarse, entre otros, el

1 Vid. VILLORIA, M./JIMÉNEZ, F., en "La corrupción en España (20032010): datos, percepción y efectos”, Revista Española de Investigaciones Sociológicas, 138, abril-junio 2012.

2 Dicho esplendor de la actividad inmobiliaria se reflejó, en el notable incremento del número de viviendas. Así se pasó de construir en España, 250.000 casas en 1997 a 800.000 en 2006. Vid. GÓRRIZ ROYO, E., "Corrupción urbanística: análisis criminológico y respuestas jurídicopenales" en Corrupción pública: cuestiones de política-criminal (I), dir. Jareño Leal, A., Madrid, 2014, págs. 96 y 97. El fuerte crecimiento de las viviendas se dejó notar en Comunidades como la Valenciana, donde el propio Síndic de Greuges en su Informe de 2006 (pág.35), presentado ante Les Corts Valencianes, alertaba del incremento de quejas presentadas ese año en materia de urbanismo y vivienda (vid. www.sincicdegreuges.gva.es/ informes). Con anterioridad, ya el Informe del Defensor del Pueblo de 2002, denunció la falta de principios éticos en la planificación territorial, muchas veces achacables a las propias administraciones públicas. Y alertaba de que nuestra cultura urbanística se había instalado en la peligrosa teoría “..que predica en esencia que "el mejor uso del suelo lo realizará aquella actividad que más pueda pagar por él". Vid. Informe anual 2002 y debate de las Cortes Generales, pág. 475 (vid. www.defensordelpueblo.es). Ante tal evidencia, se alzaron no pocas voces críticas que alertaban de que la potestad sobre la ordenación del uso del suelo en aquella época, propició un modelo de ciudad desconectado de cualquier cálculo de posibilidades de utilización racional de nuestros recursos naturales. Vid. PAREJO ALFONSO, L. "La ordenación territorial y urbanística en el contexto del a política económica y social del Estado" en Documentación Administrativa, n 271-272, 2005, pág. 482 . 
inédito caso "Malaya", finalmente sentenciado en 2013. ${ }^{3}$ Con el recrudecimiento de la crisis económica parecía lógico pensar que la corrupción urbanística tocaría a su fin. ${ }^{4}$ Mas es cuestionable que esto sucediera así, pues tras enjuiciarse los casos más llamativos de corrupción procedentes del siglo pasado (v.gr. caso "Algarrobico", caso "Andratx" o caso "Goldfinger", 5 entre otros) en tiempos recientes, siguen aflorando tramas de corrupción con origen en el urbanismo que se han ido gestando mucho después de la época de desenfreno urbanístico de los años 90. ${ }^{6}$ Estos casos, que datan de principios del s. XXI y siguen aún siendo investigados en la actualidad, suscitan la duda de si tienen, como signo distintivo, esa vinculación a la corrupción política, más característica de la corrupción reciente en nuestro país y, por tanto, si con preferencia su autoría es imputable a

3 Vid. los seis tomos de la SAP de Málaga, sección 1 ${ }^{\mathrm{a}}$, de 4 de octubre de 2013 que resuelve el llamado caso "Malaya", cuyos hechos fueron denunciados en 2005 .

4 Y ello, no tanto porque la regulación penal hubiera demostrado una mayor eficacia práctica, sino ante todo porque el urbanismo fue considerado el "motor" de nuestra economía hasta entrado el s.XXI. De modo que era esperable que durante los años de crisis económica se produjera un receso en la comisión de conductas corruptas en dicho ámbito de la actividad administrativa.

5 Con respecto al caso del "Hotel Algarrobico" (Almería), vide la STS 18 febrero 2011; el caso "Andratx", fue enjuiciado en la STS núm. 1127/2009, Sala de lo Penal, Sección 1, de 27 noviembre. Y el llamado caso "Goldfinger", fue enjuiciado por la SAP Málaga 18 octubre 2016.

6 A tal efecto considérense, entre otros, la trama urbanística del caso "Pretoria", reabierto en 2009 ante la Audiencia Nacional y que remite a unos hechos acontecidos entre los años 2000 y 2008. O téngase en cuenta las operaciones urbanísticas ilícitas que dieron base al "caso Gürtel”, relativas a las recalificaciones de terrenos en los ayuntamientos de Boadilla del Monte, Majadahonda, La Nuncia, Arganda del Rey y Marbella. También cabe citar el denominado caso "Auditorio" en el que, el presidente de la Comunidad Autónoma de Murcia, estaba siendo investigado -al cierre de este trabajo- en relación a supuestas irregularidades en el proceso de adjudicación, construcción y recepción de un auditorio en Puerto Lumbreras, entre 2006 y 2011, época en que fue alcalde de dicho municipio (vid. El País 20/02/2017 y El Mundo 2/03/2017). 
autoridades con competencias en urbanismo y no tanto a funcionarios técnicos. Es esta una cuestión cuyo estudio desde la perspectiva criminológica podría darnos la clave para mejor caracterizar la corrupción urbanística contemporánea de modo que conviene analizarla siquiera sea de forma instrumental. Al respecto, conviene reparar en que en los casos que aún siguen sub iudice, la corrupción urbanística aparece engarzada en tramas más amplias de corrupción política, que suelen arrastrar imputaciones por malversación y cohecho, entre otros delitos contra la Administración pública. Esta tendencia parece afianzarse, si atendemos a la percepción de la corrupción en nuestro país, según muestran sucesivos estudios, ${ }^{7}$ y los últimos Informes de Transparencia internacional de 2016 y 2017. Según el informe de 2016, “....en su conjunto, España no tiene corrupción sistémica, como ocurre en un gran número de países, sino múltiples escándalos de corrupción política en los niveles superiores de los partidos y de los gobiernos..." (cursiva añadida). ${ }^{8}$ Así pues, a nivel sociológico parece claro un arraigamiento de la corrupción de corte político en los gobiernos de los distintos niveles territoriales (estatal, autonómica y local), siendo todavía un foco de atracción para ello, la actividad urbanística.

De hecho, según el Informe de 2017 “....aunque el enfriamiento de la economía en el sector urbanístico, permite pensar que los casos de corrupción se han reducido en ese ámbito, las constantes irregularidades en la contratación pública, la lentitud de las sanciones penales, la baja intensidad de las penas en casos de corrupción relevante, la expansión de los escándalos a las instituciones clave del Estado, la opacidad y parcialidad en la toma de decisiones que afectan a los grupos de interés más poderosos (banca, energía,

7 Las encuestas realizadas por el CIS, muestran que para los españoles la corrupción constituye el segundo problema más preocupante del país $(39,6 \%)$, solo superado por el paro (63,3 \%). Vid. Barómetro del CIS-mayo 2018 http:// www.cis.esww.cis.es/cis/opencms/ES/NoticiasNovedades/InfoCIS/2018/Documentacion_3213.html (última consulta: 6 de junio de 2018).

8 Vid. "Índice de Percepción de la Corrupción 2016: Urge abordar el círculo vicioso de corrupción y desigualdad. El ascenso de políticos populistas en numerosos países es una señal de alerta”, p. 2. 
telecomunicaciones, etc...) y la percepción de politización en el funcionamiento de la justicia explican bien la tendencia negativa que se mantiene en este Índice..." (cursiva añadida). ${ }^{9}$

$\mathrm{Y}$ es que, en efecto, parece evidente que el cambio de ciclo económico en que incurrió nuestra economía a causa de la recesión económica de los años 2008 a 2011 debiera haber supuesto, cabalmente, un freno a las tramas de corrupción urbanística. ${ }^{10}$ Ante todo porque -según se indicó- el sector urbanístico e inmobiliario dejó de ser, durante los años 2011 a 2014, el motor de nuestra economía. No obstante, pudiera ser que, enmascarada bajo aquella tendencia económica, se hubiera dado más bien un enfriamiento transitorio de aquella clase de corrupción, de modo que tan solo la intensidad de dichas tramas hubiera disminuido. Ello casa bien con la evidencia de que no nos hemos deshecho por completo de las asentadas estructuras de patronato $y$ clientelismo que, sobre todo en el ámbito local, ${ }^{11}$ sirvieron de mimbres a la corrupción de autoridades y funcionarios; ${ }^{12} \mathrm{ni}$ de las expandidas prácticas ilegales en torno a la toma de decisiones relevantes en la planificación de urbanismo ni, sobre todo, de la proyección de dichas prácticas a los convenios ${ }^{13}$ o a la contratación en materia de urbanismo. ${ }^{14}$ A ello hay que unir que

9 Según el Informe de 2017 (págs.2-3), nuestro país sería “.. el país de Europa en el que más ha empeorado la percepción de corrupción y su situación en el ranking de países (de menos a más corruptos)."

10 Vid. GÓRRIZ ROYO, E., M., "Corrupción urbanística: Análisis criminológico y respuestas jurídico-penales" en Corrupción pública: cuestiones de política criminal (I), 2014, Madrid, págs.142-143.

11 Vid. HEYWOOD., P. "Political corruption: Problems and Perspectives", Political studies, XLV, 1997, págs. 417-435.

12 Vid. VERCHER NOGUERA, A., "La corrupción urbanística. Una nueva expresión delictiva" en Claves de la razón práctica, $\mathrm{n}^{\circ}$. 139, 2004, pág. 28.

13 Vid. MARTÍN PARDO, A., quien destaca el papel de los convenios urbanísticos para facilitar el secretismo, en Los daños sociales derivados del delito urbanístico, Valencia, 2017, pág.205.

14 Vid. JAREÑO LEAL, A., "La corrupción en la contratación pública" en Corrupción pública: cuestiones de Política Criminal (I), Jareño Leal (dir.), $1^{\mathrm{a}}$ ed., 2014, p. 149 y ss. 
el resurgir económico de las compañías y empresas constructoras y promotoras españolas así como su dominio en el ámbito internacional es una evidencia indiscutible en nuestros días. De modo que, tras el hundimiento de las compañías constructoras domésticas, con el estallido de la burbuja inmobiliaria en la primera década de este siglo, muchas de ellas acometieron profundas operaciones de rediseño a raíz de lo se han convertido, en tiempos recientes, en multinacionales de éxito. ${ }^{15}$ El origen de esta conversión de las empresas constructoras, cabe ubicarlo en la crisis financiera de 2009, lastrada por la explosión de la burbuja inmobiliaria. No obstante, en el ámbito de la construcción dentro de nuestras fronteras, el panorama es diverso pues, pese a apreciarse un crecimiento en la cifra de visados de viviendas que evidencia una tímida recuperación del sector, no parece que se hayan adoptado las medidas suficientes para prevenir otra crisis similar. ${ }^{16}$ De no poner medios, podríamos de nuevo encontrarnos en un escenario similar al de principios del s.XX, proclive a fomentar la corrupción urbanística.

La idea de un resurgimiento de la corrupción en el ámbito urbanístico, se vería reforzada además por el dato según el cual, durante la citada crisis económica, ha aumentado la desigualdad entre las diversas clases sociales. De modo que el empobrecimiento de amplias capas de población lastradas por las cargas inmobiliarias que ha supuesto la aspiración de adquirir en propiedad una vivienda, coincide llamativamente con el enriquecimiento de grupos cada vez más reducidos de élites, que apenas se han visto perjudicados por aquel declive económico y que van

15 Los datos en el ámbito internacional parecen inapelables: cinco compañías del sector español de la construcción figuran entre las 30 primeras del mundo, siendo nuestro país, después de China, el segundo en facturación internacional (60.000 millones de dólares, en 2017), superando con estas cifras a países como Estados Unidos o Francia, entre otros. Vid. "La década prodigiosa de las constructoras españolas" en El País, 4 de mayo de 2018 (www.elpais.es)

16 Vid. "Las cicatrices sin cerrar de la última burbuja inmobiliaria" en El País, 6 de mayo de 2018 (www.elpais.es). 
a seguir invirtiendo en este sector productivo. ${ }^{17}$ Aún cundo este no es un trabajo centrado en el análisis sociológico y criminológico, cualquier reflexión acerca de los problemas no resueltos en la regulación de las prevaricaciones urbanísticas ha de tener en cuenta las conclusiones a que llegan los estudios de aquella índole. Entre ellas destaca la idea de que, en la realidad reciente, la corrupción que más arraigo tiene en el urbanismo es la de carácter político. ${ }^{18}$

Precisamente por ello, es oportuno cuestionarse si la última reforma de las prevaricaciones urbanísticas, en 2010, acertó con las modificaciones introducidas o, por el contrario, las mismas no incidieron en los principales focos de corrupción en urbanismo. Ante todo, porque, como luego analizaremos, el legislador penal de 2010 cargó las tintas sobre las modalidades de prevaricación urbanística del apartado $1^{\circ}$ art.320 CP, que pueden llevarse a cabo por autoridades, incluyendo cargos políticos, pero, sobre todo, en la práctica, se cometen por funcionarios públicos (según el art.24.2 CP). Puede decirse, por tanto, que aquella reforma incidió en una clase de corrupción urbanística, de corte administrativo. Ello contrasta, a mi modo de ver, con los citados estudios sobre corrupción en nuestro país, donde se apunta que no existe tanto una corrupción de índole administrativa cuanto, mayoritariamente, de carácter político. ${ }^{19}$

17 También esta tendencia se constata en el citado informe donde se destaca que nuestro país “...tiene un problema de corrupción política muy serio y se tiene que afrontar de manera integral y sin parches.” Así pues, nos situaríamos "...en un entorno en el que la desigualdad crece y los esfuerzos de salir de la crisis se distribuyen de forma inequitativa a juicio de la mayoría de la ciudadanía consultada en diversas encuestas." Vid. Informe de Trasparencia internacional (2016), Op. cit.p. 3.

18 Vid. VILLORIA, M. /JIMÉNEZ, F., quienes diferencian entre estas clases de corrupción dependiendo, básicamente, de si están implicados responsables políticos o funcionarios o empleados públicos, en «La corrupción en España (2004-2010): datos, percepción y efectos», en Revista Española de Investigaciones Sociológicas, 138, abril-junio, 2012, págs.110, 115 y 129.

19 Vid. ampliamente MARTÍN PARDO, A., para quien el desarrollo de la corrupción urbanística se ha debido, entre otros factores, a la participación, 
Si esto es así, cuanto menos hay que sopesar si, en aras de una mayor eficacia en la persecución de estos ilícitos, no sería preciso prestar mayor atención a las prevaricaciones que pueden cometer quienes ostentan cargos políticos en materia urbanística -es decir, autoridades, a efectos del art. 24.1 CP-, y están legitimados, por tanto, para adoptar decisiones en esta materia (v.gr. alcaldes, concejales y otros cargos de designación política, en el ámbito autonómico y local) ${ }^{20} \mathrm{~A}$ este respecto, habrá que revisar el concepto de autoridad así como el de funcionario público a efectos penales, a la luz de la regulación introducida, en el ámbito administrativo, por el Real Decreto 5/2015, de 30 de octubre que aprueba el Texto refundido de la Ley del Estatuto Básico del Empleado Público. Como también veremos, las autoridades intervienen, ante todo, en las prevaricaciones urbanísticas del apartado $2^{\circ}$ del art. $320 \mathrm{CP}$, delito que, bajo la citada reforma penal de 2010, solo experimentó mejoras de carácter técnico. Cabe plantearse, por tanto, si, ante la escasa atención legislativa prestada a las prevaricaciones del apartado $2^{\circ}$ del art.320 CP y los datos criminológicos recientes, este precepto no merecería alguna modificación con la que hacer más eficaz la intervención penal en este ámbito. El estudio de aquellos delitos también cobra relieve a raíz de resoluciones recientes que afectan a nuestro país, como la trascendental STEDH de 8 de marzo de 2016. En resumen, la misma condena a España por vulnerar el art.6.1 del CEDH (presunción de inocencia) al dictarse, en sede de revisión, una sentencia que, como luego veremos, condenó a los acusados -cuatro concejales y, por tanto, autoridades- por el delito del art.320.2 CP, sobre la base de una reinterpretación

directa o indirecta de todos los agentes sociales en los beneficios del urbanismo atroz, en Los daños sociales ..Op.cit. págs. 186 a 206.

20 De hecho, entre las recomendaciones del citado Informe (2016, pág. 3), se sugieren "... un conjunto de reformas integrales en sus niveles de transparencia, rendición de cuentas, integridad, independencia de los órganos fiscalizadores y de control",. Mientras que en el Informe de 2017 (pág.4), abiertamente se solicita una Ley "ómnibus" contra la corrupción (vid. https:// transparencia.org.es/ipc-2017). 
del elemento subjetivo de aquel delito, sin dar audiencia a los mismos, que, en primera instancia, habían sido absueltos. ${ }^{21}$

A la vista de todo lo anterior, cabe cuestionarse: ¿ha redundado la reforma penal de 2010, en una mayor eficacia en la persecución de estos delitos en sus más de siete años de vigencia?; y unido a lo anterior ¿son los tribunales reticentes a aplicar las prevaricaciones introducidas en el art.320 CP?. En suma, ¿cabría plantear de lege ferenda aspectos susceptibles de reforma?

Así las cosas, los objetivos de este trabajo serían, en primer lugar, delimitar una interpretación los delitos del art.320 $\mathrm{CP}$ respetuosa con los principios penales y, a raíz de ello, en su caso, plantear mejoras para una aplicación más garantista de las prevaricaciones urbanísticas que no descuide una mejor eficacia aplicativa. A este respecto, en segundo lugar, se confrontará la regulación actual del art.320 CP, en sus dos apartados, con la aplicación práctica más reciente de las prevaricaciones urbanísticas, con vistas a detectar y analizar los posibles problemas que estén lastrando una aplicación eficaz de dichos delitos. Ni del primer aspecto ni del segundo parecen existir, tras las reformas penales de 2010 y 2015, demasiados estudios. ${ }^{22} \mathrm{O}$ al menos son escasos los trabajos que proporcionan -en último lugar-, unas conclusiones acerca de los problemas que la regulación actual

21 Como luego veremos, en la reciente STS de 24 de febrero de 2017, se declaró haber lugar al recurso de revisión de la sentencia condenatoria, esto es, la SAP de Granada núm. 502/2011, de 28 de julio de 2011 (Sección 1ª) procediendo a su anulación.

22 Sin perjuicio de ello, existen, desde luego, trabajos específicos que, desde un diverso enfoque, abordan con profundidad los delitos del art. $320 \mathrm{CP}$. Al respecto, entre otros, vide POMARES CINTAS, E./BERMEJO CHAMORRO, A.J., "¿Era necesario reformar los delitos urbanísticos? Especial referencia a los delitos de corrupción urbanística y a su trayectoria jurisprudencial", en UNED, Revista de Derecho penal y Criminología, $3^{\mathrm{a}}$ Época, $\mathrm{n}^{\circ}$ 6, 2011, págs. 109 a 150. Vid. Grupo de Estudios de Política Criminal, Una regulación alternativa contra la corrupción urbanística y otras conductas delictivas relacionadas. 2010, Valencia-Málaga, pág. 26 a 40. 
del art.320 CP no resuelve y unas propuestas de lege ferenda, acerca de cómo solucionar dichas dificultades.

Antes de acometer estos objetivos creo oportuno recordar, brevemente, la historia de estas prevaricaciones en el marco del Título XVI, Capítulo I del Código penal, con la finalidad de mejor entender de dónde proceden los problemas aplicativos que se puedan estar dando, actualmente, en la práctica judicial.

\section{Evolución histórica y fundamentación político-criminal}

El Código penal de 1995, aprobado en 1996, introdujo por primera vez en la historia de nuestro país, unos delitos específicos en materia urbanística, previstos en el Capítulo I del Título XVI, los llamados "Delitos sobre la Ordenación del Territorio" (arts. 319 y $320 \mathrm{CP}$ ). El grupo de delitos del art. 319 $\mathrm{CP}^{23}$ fue denominado, comúnmente, como "delitos urbanísti$\cos " .{ }^{24}$ Por su parte el art.320 CP preveía dos delitos especiales, en cuanto que solo autoridades y funcionarios públicos podían cometer las siguientes conductas: la contemplada en el apdo. $1^{\circ}$, resultaba novedosa en relación con el art.404 CP, si bien podía

23 En los dos primeros apartados del art.319 CP -aprobado en 1995-, se regularon, delitos cometidos por promotores, constructores y técnicos directores, consistentes, a grandes rasgos, en llevar a cabo construcciones y edificaciones sin autorización -apdo. $1^{\circ}$ - o sin licencia autorizable -apdo. $2^{\circ}$ - en determinados suelos no urbanizables -apdo. $2^{\circ}$ - y otro tipo de lugares especialmente sensibles -apdo. $1^{\circ}$ - (viales, zonas verdes, dominio público, lugares con valores reconocidos administrativamente como paisajísticos, ecológicos, históricos, artísticos y culturales o por los mismos motivos hayan sido considerados de especial protección). En el apartado $3^{\circ}$ se introdujo, novedosamente, la medida de demolición de la obra, como potestad facultativa, a cargo de jueces y tribunales.

24 Para un análisis de los mismos vid. ACALE SÁNCHEZ, M., Delitos urbanísticos, Barcelona, 1997, pág. 277 y ss. GÓRRIZ ROYO, E., Protección penal de la Ordenación del Territorio. Los delitos sobre la Ordenación del Territorio en sentido estricto, Valencia, 2001, passim. BOLDOVA PASAMAR, M.A., Los delitos urbanísticos, Barcelona, 2007, passim. 
reconducirse, desde la perspectiva material, a una participación en aquel clásico delito. Y ello porque consistía, básicamente, en "informar favorablemente", a sabiendas de su injusticia, proyectos de edificación o la concesión de licencias "contrarias a las normas urbanísticas vigentes." En el segundo apartado del art.320 CP se castigaban conductas, materialmente, semejantes a la del art.404 CP, pues consistían en resolver o votar a favor de la concesión -había que entender- de los anteriores proyectos y licencias.

Interesa destacar que, la introducción del art.320 así como de otras prevaricaciones especificas (vid. art.322 y 329 $\mathrm{CP}){ }^{25}$ supuso una destacable novedad en nuestro ordenamiento jurídico, de modo que es el legislador penal de 1995 ensanchó considerablemente la responsabilidad funcionarial mediante aquellas clausulas incriminatorias en el ámbito del urbanismo y la ordenación del territorio.

Es interesante revisar los fundamentos político-criminales por los que se introdujeron expresamente, pues con la previsión de delitos como los del art.320 CP, nuestro ordenamiento jurídico-penal pasó de un panorama legislativo carente de posibilidades expresas de responsabilizar en sede judicial a los funcionarios informantes en el ámbito urbanístico, a un marco punitivo que ofrecía diversas posibilidades para ello. Así, con las figuras de los apartados $1^{\circ}$ y $2^{\circ}$ del art. $320 \mathrm{CP}$, se posibilitó, el castigo de funcionarios públicos y autoridades operantes en el ámbito de la ordenación del territorio y el urbanismo. Una poderosa razón para ello pudo ser el que estos preceptos cumplieran con una función de recordatorio, para jueces, tribunales y fiscales, de modo que a partir del CP de 1995 podían acudir a aquellas prevaricaciones específicas para así superar complejos problemas dogmáticos planteados en materia de autoría, participación y concursos de delitos. Derivado de ello, la introducción de estas prevaricaciones específicas tuvo dos importantes

25 Vid. GONZÁLEZ CUSSAC, J.L., El delito de prevaricación de autoridades y funcionarios públicos (2 $2^{\mathrm{a}}$ ed.), Valencia, 1997, pág. 147 y ss. 
efectos: en primer lugar, desplazar la calificación de las conductas allí tipificadas como participación -necesaria o no-, en los respectivos delitos previstos para los particulares actuantes en el ámbito urbanístico (es decir, los delitos del arts.319), al ser preferente el castigo en concepto de autor de los delitos del art. $320 \mathrm{CP}$ so riesgo de vulnerar el principio de legalidad penal. Y, como segundo efecto, por imperativo de aquel mismo principio penal, funcionarios y autoridades que cometieran las conductas del art. $320 \mathrm{CP}$ podían ser castigados como autores de los delitos allí previstos, con preferencia a ser calificados de partícipes en un delito del art. $404 \mathrm{CP}$. Es decir, en términos generales, la prevaricación genérica del art. $404 \mathrm{CP}$ también queda desplazada, conforme al art.8.1 CP, cuando se verifiquen los requisitos típicos de alguna de las prevaricaciones específicas del art. $320 \mathrm{CP}$.

Así delimitada la eficacia de los delitos del art.320 CP, parece que su previsión expresa -y también la de los arts. 322 y 329 C.P-comportó un efecto agravatorio de la responsabilidad funcionarial. ${ }^{26} \mathrm{Y}$ ello porque conductas que, con anterioridad al CP de 1995, a lo sumo, podían calificarse como supuestos de cooperación necesaria, o, de forma más usual, mera complicidad en la figura de la prevaricación administrativa (art.404 C.P., antiguo art. 358 CP 1973) -o incluso quedar impunes-, en la

26 Vid. GONZÁLEZ CUSSAC, J.L., El delito de prevaricación ( $2^{\mathrm{a}}$ ed.), Op.cit. pág.156. DE LA MATA BARRANCO, N., "El art.320.1 C.P.: prevaricación específica en caso de informes favorables a proyectos de edificación o concesión de licencias contrarias a las normas urbanísticas", en Delitos contra el urbanismo y la ordenación del territorio, (ed. DE LA MATA BARRANCO, N.) Oñate, 1998, pág.140. GÓRRIZ ROYO, E., Los delitos de prevaricación urbanística, Valencia, 2004, pág.379. Desde una perspectiva político-criminal, otros autores entendieron que los delitos del art.320 CP privilegiaban a los funcionarios y autoridades en comparación con las penas que les correspondería en concepto de partícipes en los respectivos tipos de los particulares. Vid. TERRADILLOS BASOCO, J., "Responsabilidad del funcionario público en delitos relativos a la ordenación del territorio y la protección penal del patrimonio histórico y del medio ambiente", en Estudios Penales y Criminológicos, n. ${ }^{\circ}$ XX, 1997, págs.313 a 332. Vid. MUÑOZ CONDE, F., Derecho penal. PE, $14^{\text {a }}$ Ed., Valencia, 2002, pág.544 y 545 . 
actualidad, pueden imputarse a título de autor de una prevaricación específica. La agravación que comportan estas prevaricaciones, podría estar en la base, asimismo, de la voluntas legislatoris que justificó la introducción de estos delitos.

Esto sentado, conviene apuntar una cuestión adicional que habría marcado su previsión legislativa y referida al problema de su ubicación sistemática, pues antes de la introducción de los arts. 319 y 320 en el Código penal de 1995, se barajó la alternativa de preverlos en el título relativo al orden socio-económico, ${ }^{27}$ si bien no fue esta la opción que, finalmente, prevaleció. ${ }^{28}$ Finalmente, primó la perspectiva según la cual determinadas actuaciones urbanísticas podían no solo atacar a la "ordenación del territorio" sino también al "medio ambiente", asumiéndose la proximidad conceptual de dichos intereses, ya afianzada en el ámbito administrativo. En consecuencia, el Título XVI albergó, respectivamente, delitos contra aquellos intereses colectivos en capítulos distintos, en los que, además se introdujeron específicas prevaricaciones. La previsión de estas últimas, evidenciaría una preocupación por el fenómeno de la corrupción y, asimismo, reflejaría

27 En efecto, en el Proyecto de Ley Orgánica de Código penal de 1980 se incluyeron en su Título VIII (Delitos contra el orden socio-económico) Capítulo X, rubricado "Delitos contra la ordenación urbanística" (arts.382 a 385). Se entendió que aquellos delitos "reclamados por la colectividad" tenían una importante significación social que incluso trascendía a su contenido económico. Vid. GÓRRIZ ROYO, E., Protección penal de la ordenación del territorio; Op.cit. págs.130 a 135.

28 De un lado, autores como QUINTERO OLIVARES destacaron que la “... ausencia de control democrático en los Ayuntamientos y, en general, en la ordenación del suelo, el caos urbanístico se había enseñoreado del país y a su socaire se formaron numerosas fortunas." Vid. "Observaciones sobre la parte especial del Anteproyecto de Código Penal. Delitos contra la vida, libertad y contra el patrimonio y el orden económico", en La reforma del Derecho penal, MIR PUIG, S. (ed.), Bellaterra, 1980, págs. 262 y ss. De otro, un sector de la doctrina penal criticó aquella ubicación, dada la remota relación -según se sostenía- del urbanismo con aspectos económicos. Vid. RODRIGUEZ RAMOS, L., "La protección penal del urbanismo (Pautas para criminalizar algunas conductas)" en Revista de Derecho Urbanistico, 1983, págs. 31 y ss. 
que estos tipos están provistos de un componente económico que no conviene obviar en su interpretación y aplicación práctica.

\section{Regulación vigente, tras las reformas penales de 2010 y 2015}

Casi quince años después de aquella inicial previsión en el Código penal de 1995, la reforma del Código penal realizada por LO 5/2010, de 22 de junio (BOE $\mathrm{n}^{\circ} 152$, de 23 de junio) modificó considerablemente los delitos sobre la Ordenación del Territorio (arts.319 y 320 CP). La reforma de LO 1/2015, de 30 de marzo, no afectó al art.320 CP sino solo al apartado $3^{\circ}$ del art. 319 CP. Así pues, la última vez que los delitos de prevaricación urbanística se modificaron fue por la reforma de LO 5/2010. ${ }^{29}$ Conviene, no obstante, enmarcar la reforma del art.320 CP, comentando brevemente, las modificaciones del Capítulo I, Título XVI (art.319-320 CP) para entender en su conjunto el propósito legislativo perseguido:

a) La rúbrica del Título XVI incluyó una nueva referencia al "urbanismo" y se cambió el título del Capítulo I, al aludir ahora a los "delitos sobre la ordenación del territorio y el urbanismo". ${ }^{30}$ b) En los dos primeros apartados de este precepto, ahora se castiga "llevar a cabo obras de urbanización, construcción o edificación..."' Ello conlleva el adelantamiento de la intervención penal de modo que, entre otros ${ }^{31}$, se podría abarcar parcelaciones ilegales. ${ }^{32}$

29 Vid. GÓRRIZ ROYO, E., "Los delitos sobre la ordenación del territorio" en Comentarios a la reforma penal de 2010 (dirs. ÁLVAREZ GARCIA, J./ GONZÁLEZ CUSSAC, J.L.), Valencia, 2010, pág. 367 y ss.

30 Parece que el legislador trató así de vincular el bien jurídico-penal "ordenación del territorio" con el urbanismo, pudiendo aquél seguir entendiéndose en mi opinión, como el uso racional del suelo dirigido a dotar a este recurso natural del destino que le corresponde, según su naturaleza.

31 Vid. GÓMEZ RIVERO, M.C., "Ilegalidad urbanística: acerca de los límites entre el injusto penal y las infracciones administrativas" en RECPC 19-25 (2017), pág. 13 y nota $\mathrm{n}^{\circ} 17$.

32 Según la Circular 7/2011 de la Fiscalía (pág.1773): “..es evidente que esta referencia a «obras de...» implica un adelanto en la consumación del delito 
c) En el apartado $1^{\circ}$ del art.319 $\mathrm{CP}$ se castiga realizar aquellas obras siempre que sean "no autorizables". ${ }^{33}$ Además se han elevado las penas de los delitos del apartado $1^{\circ}$ y $2^{\circ}$ del art.319 $\mathrm{CP},{ }^{34} \mathrm{y}$ se establece, como alternativa a la sanción económica, que ha de calcularse conforme al sistema de días-multa, una multa proporcional del tanto al triplo del montante del beneficio obtenido por el delito, cuándo dicho beneficio fuera superior a la cantidad resultante de aplicar aquella otra clase de multa. ${ }^{35}$ d) Se ampliaron las potestades de los jueces y tribunales para restaurar la legalidad urbanística conculcada, al prever el apdo. $3^{\circ}$ art.319 CP la medida facultativa de demolición de la obra, "..la reposición a su estado original de la realidad física alterada...”, y la indemnización a terceros de buena fe y, novedosamente, el comiso de las ganancias provenientes del delito. ${ }^{36}$ La reforma de LO 1/2015, de 30 de marzo, volvió a modificar este apartado, condicionando temporalmente la demolición de

y aleja, a su vez, la tentación de que se planteen perspectivas inacabadas del tipo cuando se trate del inicio de construcciones o de edificaciones".

33 Es decir, se incorporó al art.319.1 CP, la remisión normativa ya prevista en el aptdo. $2^{\circ}$ art.319 CP. La de este precepto permanece inalterada de modo que ahora ambos aluden a obras de urbanización, edificación o construcción "no autorizables", y por tanto, manifiestan una accesoriedad del derecho administrativo.

34 Destaca el aumento de la pena de prisión del apartado $1^{\circ}$ que ahora pasa a ser de un año y seis meses a cuatro años, mientras que la pena de prisión del apartado $2^{\circ}$ es de uno a tres años Se amplía así el plazo de prescripción de los delitos del art.319 CP, a 5 años (art.131.1 CP).

35 La multa proporcional venía siendo reclamada, con buen criterio, por la doctrina penal, como medio para luchar contra los delitos urbanísticos. Vid. POZUELO PÉREZ, L., en "La respuesta penal a la delincuencia urbanística" en "Urbanismo y corrupción" Anuario de la Facultad de Derecho de la Universidad Autónoma de Madrid, 12 (2008), pág. 76.

36 Sobre las medidas de este apartado $3^{\circ}$, en especial la demolición, y, asimismo, sobre su relación con las previsiones comunes del capítulo V del Título XVI, vid. GÓRRIZ ROYO, E., "Demolición, reposición, responsabilidad civil..." Op.cit. págs. 159 a 195. Vid. también las propuestas de "lege ferenda" que, en este sentido, plantearon POZUELO PÉREZ, L./DOPICO GÓMEZALLER, J., en "Demolición o comiso" Diario La Ley, 19 de mayo de 2008, passim. 
la obra, a la constitución de garantías que aseguren el pago de las indemnizaciones debidas a terceros de buena $\mathrm{fe}^{37}$

e) En el apartado $4^{\circ}$, se ha introducido la cláusula de responsabilidad penal directa de las personas jurídicas, estableciendo determinadas penas de multa para las que hubieran sido responsables de los anteriores delitos, de conformidad con lo establecido en el art.31 bis) CP.

Por lo que toca a las prevaricaciones especificas del art.320 CP, hay que destacar una serie de novedades que se incorporaron en 2010 y que ante todo afectaron a los delitos del apartado $1^{\circ}$ de este precepto. En particular, se introdujeron "ex novo", conductas omisivas de prevaricación en el art.320.1 CP, de manera similar a como se preveían en las prevaricaciones del art.329.1 CP (en su redacción, en parte procedente del CP de 1995 y, en parte, de la reforma de LO 5/2010). Parece evidente que la redacción de las llamadas prevaricaciones ambientales pudo influir en el legislador penal de 2010 para reformar el apartado $1^{\circ}$ art. $320 \mathrm{CP}$. En efecto, las prevaricaciones urbanísticas no pueden entenderse sin ubicarlas en el contexto más amplio de las prevaricaciones especificas, con las que no solo guardan un evidente "aire de familia" en su estructura típica, sino que además comparten una misma fundamentación político-criminal como cláusulas ampliatorias de la responsabilidad funcionarial. Veamos pues, brevemente, cuáles son sus rasgos característicos.

\section{Prevaricaciones específicas}

El Código penal de 1995 dio carta de naturaleza a las prevaricaciones del art.320 CP, en el Capítulo I del Título XVI, así como a las del Capítulo II y Capítulo III del mismo título. En

37 Vid. GÓRRIZ ROYO, E., "Delitos contra la ordenación del territorio: el condicionamiento temporal de la demolición a la constitución de garantías (art.319.3 CP)", en Comentarios a la Reforma del Código penal de 2015, (dir. GONZÁLEZ CUSSAC/coord. GÓRRIZ ROYO/MATALLÍN EVANGELIO), $2^{\mathrm{a}}$ ed., Valencia, 2015, pág. 985. 
efecto, el legislador de 1995 introdujo "ex novo" unas figuras delictivas en concreto, denominadas prevaricaciones urbanisticas (art.320 CP), prevaricaciones en el ámbito del patrimonio histórico del art.322 CP y prevaricaciones ambientales (art.329 $\mathrm{CP})$. ¿A qué responde la incriminación de todas estas prevaricaciones denominadas doctrinalmente especificas?

En líneas generales, dichas prevaricaciones se consideran así, por las particularidades que manifiestan respecto del tradicional delito genérico de prevaricación administrativa que, desde la aprobación del CP de 1995, está previsto en el art.404 CP. ${ }^{38}$ Sentada la importancia de la novedad de las prevaricaciones especificas en el CP de $1995,{ }^{39}$ ha de repararse en que aun pudiendo ser los posibles autores de estas prevaricaciones los mismos que en la prevaricación genérica, esto es, autoridades y funcionarios públicos, existen importantes diferencias entre aquéllas y ésta. ${ }^{40}$ Por otra parte, todas las prevaricaciones específicas son estructuralmente preceptos similares ${ }^{41}$ pues repiten un esquema muy parecido:

En el primer apartado de los respectivos arts. 320, 322 y $329 \mathrm{CP}$, se recoge delitos consistentes en informar un acto administrativo (licencia o autorización) contrario a las normas

38 Vid. BOIX REIG, J., "Urbanismo y Derecho penal” en Diccionario de Derecho penal económico, $2^{\mathrm{a}}$ ed., (Dir.: Boix Reig; Coord.: Lloria García), Madrid, 2017, pág.1088.

39 Vid. GONZÁLEZ CUSSAC, J.L., El delito de prevaricación ... $2^{\mathrm{a}}$ ed., Op.cit. pág. 147 y ss. GÓRRIZ ROYO, E., Delitos de prevaricación urbanística, Valencia, 2004, págs. 43 y 49.

40 En primer lugar, porque las prevaricaciones específicas aún cierran más el círculo de sujetos activos, pues solo pueden cometerse por autoridades y funcionarios que, concretamente sean competentes bien en ordenación del territorio/urbanismo, bien patrimonio histórico o bien, por último, en medio ambiente. Asimismo, entre otras diferencias, las prevaricaciones específicas representan ofensas más alejadas de la lesión al bien jurídico categorial protegido en la prevaricación genérica, es decir, el correcto desempeño de la función pública como servicio a los ciudadanos.

41 Vid. GONZÁLEZ CUSSAC, J.L., El delito de prevaricación ...2 $2^{\mathrm{a}}$ ed., Op.cit. pág. 147. 
administrativas correspondientes de específicos ámbitos (respectivamente, urbanístico, patrimonio histórico y medio ambiente). Además, como resultado de diversas reformas, el art. 320.1 CP y el art.329.1 CP castigan la omisión de determinadas infracciones que se presencien o debieran haberse impedido por funcionarios y autoridades públicas. Dichas conductas omisivas no se castigan, sin embargo, con respecto a las prevaricaciones relativas al patrimonio histórico del art.322 CP. En todo caso, aquellas ofensas, representan meros peligros abstractos respecto del citado bien jurídico categorial, si bien es cierto que -a diferencia del art.320.1 CP-, cuanto menos, el ilícito del art. 329.1 $\mathrm{CP}$ restringe el castigo, exigiendo comprobar la manifiesta ilegalidad de las licencias informadas, lo que apunta al requisito de la "arbitrariedad" de todas las conductas del precepto. ${ }^{42}$ En los apartados segundos de los arts. 320, 322 y 329 CP se prevén delitos de prevaricación en sentido estricto por cuanto consisten en votar o resolver a favor de la concesión de determinadas licencias, proyectos, instrumentos o actividades, en contra de las normas administrativas vigentes, en los respectivos ámbitos de la actividad administrativa. La principal novedad de estas prevaricaciones radicaba, por tanto, en los delitos previstos en los apartados primeros, pues allí se introdujeron conductas que, con anterioridad al CP de 1995, difícilmente podían ser castigadas como una prevaricación administrativa. En ello radicaba pues el efecto ampliatorio y agravatorio de todas las figuras de los arts.320.1, 322.1 y $329.1 \mathrm{CP}$, al permitir adelantar el castigo de determinadas autoridades y funcionarios públicos cuyas conductas dificilmente podian tener cabida en el delito del art. $404 C P$.

Como se ha indicado, la reforma del Código penal operada por LO 5/2010, de 22 de junio, ha modificado muchos preceptos del Título XVI. Por lo que a este estudio respecta, la principal novedad es que han asimilado los delitos del apartado $1^{\circ}$ de los arts.320 CP, a los del 329.1 CP, introduciendo en el primer

42 Vid. GÓMEZ RIVERO, C., "Ilegalidad urbanística...” Op.cit.pág.14. 
precepto la posibilidad de castigar la prevaricación urbanística en modalidad omisiva, bajo determinados requisitos que seguidamente se analizarán al hilo del análisis de las prevaricaciones urbanísticas.

\section{Prevaricaciones urbanísticas del art. $320 \mathrm{CP}$}

De una visión de conjunto de los tipos penales del actual art.320 CP cabe apreciar que prevé dos clases de ilícitos: de un lado, los que, procedentes de la originaria redacción del Código penal de 1995, se construyen sobre la base del "iter" característico del proceso de concesión de licencias en materia urbanística. De otro lado, los que se introdujeron por la reforma de LO $5 / 2010$, de 22 de junio que añadió conductas omisivas y otras relacionadas con ilicitudes cometidas en el proceso de aprobación de determinados instrumentos del planteamiento.

El estudio de aquel primer grupo de prevaricaciones urbanísticas más antiguas, remite, necesariamente, a un análisis de la legislación administrativa que regula el procedimiento de concesión de permisos, licencias y autorizaciones en urbanismo y ordenación del territorio en el Derecho urbanístico autonómico y local. Por otro lado, las llamadas "prevaricaciones omisivas" y relativas a las modificaciones del planeamiento, remiten al estudio de las normas por lo general, autonómicas y locales que, en materia de ordenación del territorio y urbanismo, regulan la función inspectora $y$, también las normas que suelen aprobarse en el ámbito municipal, relativas al planeamiento urbanístico.

La incorporación de estos últimos tipos penales distorsionó, en cierto modo, el propósito inicial del legislador penal de 1995 de atacar el fenómeno de la corrupción originada solo en torno a la concesión arbitraria de licencias urbanísticas, como una especificidad de la prevaricación administrativa genérica. Pero puesto que, como hemos visto, la corrupción urbanística ha ido evolucionando y se ha expandido a lo largo del tiempo en nuestro país y han surgido ámbitos como, por ejemplo, el de las 
reclasificaciones y recalificaciones, que han pergeñado importantes tramas corruptas que no podían ser abarcados por los tipos originales del art. $320 \mathrm{CP}$, en general esta última reforma merece una valoración positiva. No obstante, también hay que destacar ciertos aspectos criticables de la reforma de 2010, en especial, la desmesurada ampliación del tipo a través de la segunda modalidad omisiva introducida, en los términos que luego se analizarán. Asimismo, cabe apuntar algunas cuestiones objetables en tanto se ha dejado fuera del ámbito típico cualquier referencia a la contratación y a los convenios que se pueden acordar o conceder en materia urbanística y que, como la realidad criminológica demuestra, suelen ser origen de las tramas corruptas que mayores perjuicios económicos causan a los intereses generales. ${ }^{43}$ Este podría ser uno de los problemas no resueltos a nivel legislativo y que, como por ejemplo, se pone de manifiesto en la STS 550/2017, de 17 de julio (TOL6.209.557; MP: Colmenero Menéndez), no carece de importancia, en tiempos recientes. De hecho, la ausencia de cualquier posibilidad de incriminación expresa de arbitrariedades en materia de convenios urbanísticos, podría estar en la base de la moderada aplicación práctica que han tenido las prevaricaciones urbanísticas, tras la reforma operada por la LO 5/2010, de 22 de junio. Por lo general, la comisión de estos ilícitos iba unida a la de otros delitos de mayor gravedad (v.gr. cohechos, malversaciones, prevaricaciones genéricas...), lo que hizo que se desplazara la aplicación aquellas prevaricaciones debido, en unos casos, a la falta de práctica aplicativa de éstas y, en otros casos, a la aplicación de determinadas reglas concursales que hicieron prevalecer a los delitos clásicos. Así sucedió, por ejemplo, en las tramas corruptas enjuiciadas entre otros, en el llamado caso "Andratx" o en el caso "Malaya."

43 VILLORIA, M. /JIMÉNEZ, F., «La corrupción en España (2004-2010): datos, percepción y efectos», Revista Española de Investigaciones Sociológicas, 138, abril-junio, 2012, passim.

44 Vid. Caso "Malaya” (SAP de Málaga, sección 1", de 4 de octubre de 2013). El llamado “caso Andratx”, fue enjuiciado en la STS núm. 1127/2009, Sala de lo Penal, Sección 1, de 27 noviembre). 
Tras la entrada en vigor de la LO 5/2010 puede seguir apreciándose una incidencia modesta de las prevaricaciones urbanísticas, lo que pudiera deberse a la falta de una interpretación doctrinal asentada y de una práctica aplicativa constante en torno a estos delitos. Con el propósito de contribuir modestamente a asentar aquella interpretación y a apoyar dichas prácticas, el siguiente análisis se centrará en las modificaciones introducidas por la LO 5/2010 en el art. 320 CP. Al propio tiempo se expondrá cómo esta legislación puede responder a alguno de los problemas que venían dificultando la aplicación anterior, de los tipos de prevaricación específica, así como las posibles mejoras pendientes.

\subsection{Elementos del delito}

\section{1.a) Bien jurídico y sujeto pasivo}

Antes de comenzar con el análisis de estas conductas, han de destacarse tres aspectos comunes a todas ellas y que son de capital importancia. En primer lugar, es preciso reparar en el bien jurídico tutelado y el injusto típico característico, respectivamente, de los delitos del apartado $1^{\circ} \mathrm{y}$ de apartado $2^{\circ}$. Con respecto al bien jurídico protegido, es una idea común señalar que estamos ante delitos pluriofensivos, lo que implica que a través de ellos se tutelan dos bienes jurídicos. De un lado, se protege un bien jurídico categorial -también tutelado en el art.404 CP- es decir, el correcto ejercicio de la función pública, como servicio ofrecido a los ciudadanos y guiado, en consecuencia, por el interés general, según la legalidad vigente. Conviene incidir en que dicho funcionamiento correcto es considerado un interés jurídico-penal por cuanto se trata de un servicio que se presta a los ciudadanos. Al propio tiempo, se tutela un bien jurídico de corte colectivo, esto es, la ordenación del territorio, entendido como el uso racional del suelo tendente a dotar, a cada parte del territorio, del destino que le corresponde conforme a su naturaleza. ${ }^{45}$

45 Vid. GÓRRIZ ROYO, E., Los delitos de prevaricación urbanística...Op.cit. págs. 123 y 124. 
Pues bien, si esto es así, conviene advertir que los delitos del apartado $1^{\circ}$ art.320 CP tienen un injusto típico distinto a los del apartado $2^{\circ}$. Todos ellos son delitos de peligro. A este respecto se han podido desarrollar diversas posturas que explican, desde la perspectiva político-criminal, a qué responde aquella configuración de delitos de peligro en este precepto, apuntando que, desde la perspectiva material, pueden entenderse bien como actos preparatorios de los delitos del art. $319 \mathrm{CP}$, bien como conductas de participación en la prevaricación del art. 404 CP. Sin obviar dichas posturas, lo cierto es que se atenderá con preferencia a una interpretación objetivo-formal basada en el tenor literal del art. $320 \mathrm{CP}$ para, en concreto, apreciar que los delitos del apartado $1^{\circ}$ manifiestan, con respecto al bien jurídico "ordenación del territorio" un mero peligro abstracto. Si bien, en relación con el bien jurídico "correcto funcionamiento de la administración", serían de peligro concreto ${ }^{46}$ Por su parte, los delitos del apartado $2^{\circ}$ constituyen una ofensa muy próxima, en términos normativos, a la lesión con respecto al correcto funcionamiento de la administración pública, sobre todo en la modalidad de "resolver". Mientras que respecto al bien jurídico "ordenación del territorio" comportarían un ilícito de peligro concreto. ${ }^{47}$ Esta postura es, asimismo, coherente con la de quienes sostenemos que en el art. $319 \mathrm{CP}$ se prevén delitos de lesión respecto a aquel bien jurídico colectivo.

Al margen de estas precisiones teóricas, ha de repararse en que, en sede judicial, ha habido una evolución muy notable a favor de la tutela del bien jurídico-penal, ordenación del territorio a través de los delitos del art.320 CP. Cabe citar a tal efecto, la postura de la STS del llamado "caso Andratx", núm. 1127/2009 (Sala de lo Penal, Sección 1), de 27 noviembre, en la que, se confirma la condena de la Audiencia Provincial de

46 Vid. GÓRRIZ ROYO, E., Los delitos de prevaricación urbanistica...Op.cit. págs. 267

47 Vid. GÓRRIZ ROYO, E., Los delitos de prevaricación urbanística...Op.cit. págs. 291 y 292. 
Baleares (Secc. $2^{\mathrm{a}}$ ) contra, entre otros, el Alcalde-presidente de la citada localidad por un delito de prevaricación urbanística (art.320 CP) y otro delito sobre la ordenación del territorio del art.319.1 CP. ${ }^{48}$ Dejando para un momento posterior la aplicación que, en esta sentencia, se realiza de los arts. 319 y $320 \mathrm{CP}$, de ella destaca la postura tendente a dotar de relevancia a los ilícitos allí previstos en tanto instrumentos de tutela de la ordenación del territorio. Dicha tendencia también se aprecia en resoluciones como la STS de 19 de julio de 2017, FD $5^{\circ}$ (MP: Jiménez García; TOL6.211.155), en que se asume la declaración de la sentencia de instancia que condena por un delito del art. 320.2 $\mathrm{CP}$, admitiendo al tal efecto que "la importancia del bien jurídico protegido por el delito que ahora nos ocupa, se garantiza en nuestro Ordenamiento jurídico, en cuanto ahora nos interesa, mediante el estableciendo de un procedimiento de otorgamiento de las licencias de obra en el que se asegure que la normativa urbanística es respetada en todos y cada uno de los municipios de España, por pequeños que sean" (cursiva añadida). Sin embargo, frente a esta línea jurisprudencial, aún cabe advertir una reticencia de los tribunales a la protección de aquel bien jurídico a través de los delitos del art.320 CP cuando, en ocasiones, su aplicación queda postergada frente a la calificación de determinadas conductas conforme al art.404 CP y otros delitos contra la Administración pública. Pese a ello, puede sostenerse, como veremos que la relación concursal entre el art.404 CP y los delitos del art.320 CP es de especialidad, de modo que, cuando concurran, la aplicación de estos delitos más específicos debería desplazar a aquella otra prevaricación más genérica.

Por último, y en consecuencia con todo lo anterior, cabe delimitar el sujeto pasivo de los delitos del art. $320 \mathrm{CP}$, identificándolo con la colectividad, sin perjuicio de que, en concretos casos, la propia Administración se pueda considerar perjudicada y emprenda por ello las correspondientes acciones, incluso penales.

48 Con respecto sólo a este último delito, se aprecia además la agravante de prevalerse de su carácter público (art.22.7 CP). 
5.1.b) Sujeto activo: empleados públicos y concepto penal de funcionario y autoridad

Con respecto al sujeto activo, la referencia a las "autoridades y funcionarios públicos" en los apartaros $1^{\circ}$ y 2 del art. 320 CP no deja lugar a dudas acerca de que allí se prevén delitos especiales. Concretamente propios, por cuanto la condición de funcionario público o autoridad, es determinante para la existencia del delito, porque pertenece a su misma esencia, es decir, a su injusto típico. De manera que, si dicha cualidad especial del sujeto no se diera, el hecho devendría atípico, dado que no existe correspondencia con el ilícito de ningún otro delito común. Como es sabido, dichas referencias habrán de interpretarse en los términos del art.24 CP. ${ }^{49}$ Este entendimiento del delito conforme al sujeto activo es, a mi modo de ver, preferible a su configuración como delitos de infracción de deber, como se desprende de la citada STS de 19 de julio de 2017 (FD 2 ${ }^{\circ}$ ), en la que se sostiene:

“(..) es claro que el delito del art. 320 del Cpenal se adscribe a la calificación de los delitos de infracción de un deber, esto es el tipo penal sanciona a quienes teniendo una determinada posición de garante respecto de la inviolabilidad del bien jurídico, quebrantan tal deber de control y vigilancia del cumplimiento del ordenamiento jurídico, que en el presente caso se centra en el cumplimiento del procedimiento de otorgamiento de las licencias, deber que no desaparece porque no exista el aviso de ilegalidad del Secretario de la Corporación, que en el presente caso no existió (...)" (cursiva añadida).

Resulta criticable la aplicación de la categoría de delitos de infracción de deber a delitos que, como los del art.320 CP, sean cometidos por funcionarios públicos o autoridades apelando a la "posición de garante respecto de la inviolabilidad del

49 Vid. VALEIJE ÁLVAREZ, I., "Reflexiones sobre los conceptos penales de funcionario público, función pública y "personas que desempeñen una función pública”, en C.P.C., n 62, 1997, págs. 435 a 507 
bien jurídico" pues de un lado, apelar genéricamente al deber de tutelar el interés protegido para justificar esta clasificación es un argumento muy vago; pero es que además aquella categoría sirve, en muchos casos, como expediente dogmático con el que ampliar la responsabilidad penal más allá de lo permitido por la tipicidad. ${ }^{50}$ Frente a este entendimiento, para ser autor de un delito del art. $320 \mathrm{CP}$ se requiere, no solo tener un genérico deber de tutela del bien jurídico sino, como luego se desarrollará, probar que un concreto funcionario o autoridad asumió competencias especificas en determinadas fases de un concreto proceso administrativo relativo al urbanismo o la ordenación del territorio (v.gr. concesión de licencias, clasificación, etc.); además, habrá que demostrar que, durante la comisión del delito, el sujeto era consciente de todo ello. Y no huelga recordar que, para devenir autor, no basta comprobar la contravención de un genérico deber de tutela que, por ser funcionario o autoridad público, se tenga encomendado, sino que, ante todo, hay que probar la efectiva ejecución de las acciones típicas previstas en el art. $320 \mathrm{CP}$, que luego analizaremos.

A ello hay que añadir que la referencia normativa a "funcionarios y autoridades públicas" no es un rasgo exclusivo del art.320 CP, sino que el empleo de dichos términos normativos reglados también se reproduce en las restantes prevaricaciones específicas, así como en la genérica del art.404 CP y en la mayoría de delitos contra la Administración pública. Por todo ello, considero más coherente con la regulación penal española, entender dichos delitos como especiales propios y acudir al art.24 $\mathrm{CP}$ y a la doctrina y jurisprudencia penales que han desarrollado el concepto penal de autoridad y al de funcionario público, para interpretarlos, partiendo de que son conceptos independi-

50 Es decir, conforme el entendimiento de los llamados delitos de infracción de deber, pudiera parecer que baste ostentar la condición de "funcionarios públicos o autoridades" para ser considerados autores de un delito del art. 320 $\mathrm{CP}$, pues aquellos servidores públicos siempre tendrían la citada "posición de garante" de un bien jurídico formalizado. 
entes, autónomos y más amplios respecto de los que, respectivamente, se emplean en Derecho administrativo. ${ }^{51}$

Con respecto al concepto de funcionario público, no puede desconocerse que entre la noción penal y administrativa existe cierta relación pues la primera se construye a partir de la regulación administrativa de las distintas formas en que el funcionario público puede adquirir dicha condición. ${ }^{52}$ De ahí que haya que tener en cuenta la trascendental reforma acontecida en el ámbito del Derecho administrativo con respecto al concepto de funcionario público, pues, en la actualidad, se emplea con preferencia, el concepto de "empleado público". A este respecto, es preciso citar las últimas novedades introducidas por el Real Decreto Legislativo 5/2015, de 30 de octubre, por el que se aprueba el texto refundido de la Ley del Estatuto Básico del Empleado Público ${ }^{53}$ (en adelante LEBEP de 2015). Conforme a dicho Estatuto, en el concepto de "empleado público" se incluye a "quienes desempeñan funciones retribuidas en las Administraciones Públicas al servicio de los intereses generales". Y concretamente se ofrece una clasificación de "empleados públicos" que incluye: "a) Funcionarios de carrera. b) Funcionarios interinos. c) Personal laboral, ya sea fijo, por tiempo indefinido o temporal. d) Personal eventual." (art.8). Todos estos status del personal al servicio de la Administración, son considerados, actualmente, empleados públicos. No obstante, por lo que toca a este trabajo interesa determinar si, a efectos penales, todos ellos pueden ser considerados "funcionario público" conforme al art.24.2 CP.

51 Vid. OCTAVIO DE TOLEDO, E., La prevaricación de funcionario público, Madrid, 1990, passim. VALEIJE ÁLVAREZ, I., "Reflexiones sobre los conceptos penales..” Op.cit. pág.444 y ss.

52 Y por eso, como se reconoce en la doctrina penal, el concepto de funcionario alude a concretos títulos Vid. COBO DEL ROSAL/QUINTANAR DÍEZ, "Comentario al art. 24 CP", en Comentarios al Código Penal. Tomo III. Artículos 24 a 94, (dir. Cobo del Rosal), Madrid 2000, pág. 36.

53 Este Real Decreto derogó la Ley 7/2007, de 12 de abril, del Estatuto Básico del Empleado Público. 
Con respecto al concepto penal de funcionario público, el art.24.2 CP implica, en esencia, que quien lo sea en sentido administrativo lo es también en el sentido penal, pero no a la inversa ${ }^{54}$ Como se reitera en la doctrina penal, han de comprobarse dos aspectos: el título habilitante y la participación en el ejercicio de la función pública. Pese a ello, no se puede desconocer la tendencia jurisprudencial ${ }^{55}$ en la definición del concepto de funcionario público que, en líneas generales, enfatiza el elemento material o participación en el ejercicio de las funciones públicas (art.24.2 CP). ${ }^{56}$ Sin embargo, la comprobación del ejercicio de funciones públicas es elemento necesario pero no suficiente para ser considerado funcionario público a efectos penales $;{ }^{57}$ como tampoco lo es la mera ostentación, por parte

54 Vid. DÍAZ Y GARCÍA CONLLEDO, M., voz "Autoridad y funcionario a efectos penales" en Enciclopedia jurídica básica, vol. I, Madrid, 1995, pág. 710 .

55 Vid. entre otras, la STS 166/2014, de 28 de febrero (FD $9^{\circ}$ ) donde se admite que el concepto penal de funcionario público es "marcadamente funcional"; la STS 1590/2003, de 22 de abril (FD 13) así como la STS 4 de diciembre de 2002.

56 Ello ha conducido a que, una parte de la doctrina penal, critique dicha interpretación extensiva del concepto y, con buen criterio, reivindique la importancia de comprobar además, el título habilitante para ser considerado “funcionario público a efectos penales".Vid. JAVATO MARTÍN, A.M., "El concepto de funcionario y autoridad a efectos penales" en Revista Jurídica de Castilla y León. n. ${ }^{\circ}$ 23. Enero, 2011, p. 153. RAMON RIBAS, E., "La derogación jurisprudencial del art.24.2 CP (concepto de funcionario público)", en Estudios Penales y Criminológicos, vol. XXXIV (2014), pp. 179 y 180 .

57 Entre otras resoluciones clásicas para delimitar la noción de "función pública" vid. la STS de 20 de enero de 1978 (AR 81) y jurisprudencia citada en su Considerando $1^{\circ}$. A partir de ésta y posteriores resoluciones en el mismo sentido, la doctrina penal ha configurado tres elementos para delimitar la existencia de una función pública: el subjetivo (es función pública la realizada por un ente público), el objetivo (la actividad realizada ha de estar sometida al Derecho público) y teleológico (la actividad ha de perseguir fines públicos). Vid. ORTS BERENGUER, E., "Comentarios al art.24" en VIVES ANTÓN, T.S. (coord.), Comentarios al Código penal de 1995, vol. I, 1996, pág.274. GONZÁLEZ CUSSAC, J.L., El delito de prevaricación... Op.cit.pág. 100 . 
del empleado público, del correspondiente título habilitante. En suma, el art.24.2 CP contiene un concepto "mixto", 58 de modo que, pese a que el elemento funcional se haya ensanchado más ${ }^{59}$ y cumpla con un papel delimitador, solo la comprobación de los requisitos formal y material (o funcional), permitirá otorgar el reconocimiento de funcionario a efectos penales. ${ }^{60}$

Sobre la base de todo ello, ninguna duda cabe de que, entre los llamados "empleados públicos" del art.8 LEBEP, cabe considerar funcionario a efectos penales, al llamado funcionario de carrera entendiendo por tal "...quienes, en virtud de nombramiento legal, están vinculados a una Administración Pública por una relación estatutaria regulada por el Derecho Administrativo para el desempeño de servicios profesionales retribuidos de carácter permanente." (art. 9.1 LEBEP ${ }^{61}$ ). El problema es, sin embargo, si cabe considerar funcionario público a efectos penales, también a las restantes categorías de "empleados públicos". Esto es, al llamado "funcionario interino" (art.10 LEBEP) ${ }^{62}$, al

58 Vid. las consideraciones de COBO DEL ROSAL, M., respecto al art.119.3 ACP y que, a mi entender, son extensibles al actual art. 24.2 CP, en "Examen crítico del párrafo $3^{\circ}$ del artículo 119 del Código penal español" en Revista General de Legislación y Jurisprudencia, $\mathrm{n}^{\circ}$ 212, 1962, p. 224.

59 Vid. DE LA MATA BARRANCO, N., "El funcionario público ante el Derecho penal: cuestiones generales" en Revista jurídica de Castilla y León. n. ${ }^{\circ}$ 20. enero 2010, p. 17.

60 Vid. ORTS BERENGUER, E., "Comentario al art.24” en VIVES ANTÓN, T.S. (coord.), Comentarios al Código penal de 1995, vol. 1, 1996, p. 274. GONZÁLEZ CUSSAC, J.L., El delito de prevaricación...Op.cit.p. 100.

61 El art. 9.2 $2^{\circ}$ LEBEP, remite a la ley de desarrollo que cada Administración Pública establezca “... el ejercicio de las funciones que impliquen la participación directa o indirecta en el ejercicio de las potestades públicas o en la salvaguardia de los intereses generales del Estado y de las Administraciones Públicas corresponden exclusivamente a los funcionarios públicos."

62 Según el art.10 LEBEP, por tales hay que entender a quienes “...por razones expresamente justificadas de necesidad y urgencia, son nombrados como tales para el desempeño de funciones propias de funcionarios de carrera,.." cuando se dé alguna circunstancia expresamente tasada (v.gr. plazas vacantes, sustitución transitoria, ejecución de un programa temporal, etc..) 
"personal laboral" (art. 11 LEBEP) ${ }^{63}$ y al "funcionario eventual" (art.12 LEBEP). ${ }^{64}$

Entiendo que deben ser considerados funcionarios públicos a efectos penales tanto los funcionarios interinos como el llamado "personal eventual", pues ambos grupos de empleados públicos cumplen con los dos requisitos del art.24.2 CP, esto es, poseen un título habilitante por nombramiento de autori$d a d,{ }^{65}$ y además también cumplen con el requisito material de ejercer, en efecto, la función pública. Con respecto al llamado funcionario eventual cabe destacar que, siguiendo la definición legal, requiere un nombramiento, por lo general, de autoridad competente. Ahora bien, solo ejerce funciones públicas calificadas de "confianza" o "asesoramiento especial" y con carácter "no permanente". En consecuencia, solo podrá ser considerado funcionario público a efectos penales, durante el tiempo en el que, efectivamente, esté cumpliendo con dichas funciones -en el concreto ámbito de actividad (v.gr. urbanismo)-, y no, una

63 El art. 11.1 LEBEP, define al personal laboral como “...el que en virtud de contrato de trabajo formalizado por escrito, en cualquiera de las modalidades de contratación de personal previstas en la legislación laboral, presta servicios retribuidos por las Administraciones Públicas. En función de la duración del contrato éste podrá ser fijo, por tiempo indefinido o temporal". Igualmente, el art.11.2 se remite a "las leyes de Función Pública que se dicten en desarrollo de este Estatuto...para establecer los criterios para determinar los puestos de trabajo que pueden ser desempeñados por personal laboral..."

64 Según el art.12.1 LEBEP "es personal eventual el que, en virtud de nombramiento y con carácter no permanente, sólo realiza funciones expresamente calificadas como de confianza o asesoramiento especial, siendo retribuido con cargo a los créditos presupuestarios consignados para este fin". Además de remitirse en el apartado $2^{\circ}$ a las leyes de la Función pública que se dicten para desarrollar el Estatuto en relación con este empleado (apdo. $2^{\circ}$ ), el art. 12 en su apartado $3^{\circ}$ especifica que "el nombramiento y cese serán libres" con respecto al personal eventual. Y además, el “..cese tendrá lugar, en todo caso, cuando se produzca el de la autoridad a la que se preste la función de confianza o asesoramiento".

65 Vid. VALEIJE ÁlVAREZ, I., "Reflexiones sobre los conceptos penales de funcionario..”Op.cit.pág. 458. Vid. RAMON RIBAS, E., "La derogación jurisprudencial del art.24.2 CP..” Op.cit.pág. 202. 
vez haya cesado de ejercer las mismas. Por otra parte, el llamado personal laboral también puede entenderse incluido en el concepto de funcionario público a efectos penales, siempre que los servicios retribuidos por la Administración y que efectivamente preste, sean de índole pública, es decir, impliquen ejercicio de funciones públicas. ${ }^{66}$ No obstante, puede suceder que dicho personal actúe como un particular, es decir, que preste servicios de carácter privado -bien individualmente, bien como miembro de una empresa o corporación privada-, en cuyo caso, no podrá ser tenido por funcionario a efectos penales. ${ }^{67}$ Así pues, salvo estos últimos casos, el resto de supuestos de personal considerado "empleado público" pueden reconducirse a la categoría de funcionario a efectos penales. ${ }^{68}$ En todo caso, habrá que atender además a cada tipo delictivo en concreto, ${ }^{69}$ puesto que hay

66 En el caso de ser personal laboral "temporal", solo podrá ser considerado funcionario según el art.24.2 CP, por el tiempo en que dure la prestación de su servicio. Vid. GÓRRIZ ROYO, E., Los delitos de prevaricación...Op.cit. pág.98.

$67 \mathrm{Al}$ respecto, surge también el problema de la delegación de funciones por cualquier método de gestión (contratación, concesión, etc..), habida cuenta de la extendida práctica de la externalización de servicios administrativos, en la actualidad. Pueden ser controvertidos los casos en que las delegaciones recaigan en organismos autónomos sometidos a un régimen de Derecho público y, de otro lado, cuando recaigan en entidades de Derecho público en régimen de Derecho privado. Un aspecto relevante para considerar a un sujeto, funcionario a efectos penales, será averiguar -una vez identificado el título habilitante- si la actividad le era efectivamente imputable a la Administración, como último responsable, o si aquél actuó a título de particular. Vid. GÓRRIZ ROYO, E., Los delitos de prevaricación urbanistica...Op.cit.pág. 98

68 En sentido próximo, OLAIZOLA NOGALES, quien ya admitió que podían reputarse funcionarios públicos, los que lo sean de carrera, pero además los interinos, los contratados laborales al servicio de la administración o a quien a través de un contrato, administrativo o de cualquier otra naturaleza, realice - con cierta permanencia - cualesquiera actuaciones que puedan definirse como de carácter público, en «Concepto de funcionario público a efectos penales», en Delitos contra la Administración Pública, (coord. Asúa Batarrita), Oñati, 1997, pp. 77 y ss. Vid. DE LA MATA BARRANCO, N., "El funcionario público..." Op. y loc. ult. cit.

69 Vid. GÓRRIZ ROYO, E., Los delitos de prevaricación urbanistica...Op.cit. pág. 99. 
que verificar si, en efecto, el concreto empleado público tenía las competencias exigidas para ejercer las específicas funciones públicas que le habilitaban para cometer el delito en particular.

Por otra parte, respecto a la autoría de los delitos del art.320 CP hay que tener en cuenta que -a diferencia de los delitos del art. $319.4 \mathrm{CP}-$, no se prevé una cláusula de incriminación expresa para las personas jurídicas, en relación con los delitos del art. 320 CP. Ello hace que estos delitos no se vean afectados por la referencia del apartado $2^{\circ}$ del art. 31 quinquies) $C P .{ }^{70} \mathrm{De}$ modo que si no cabe castigar expresamente a las personas jurídicas que intervienen en los delitos del art. $320 \mathrm{CP}$, cuando alguna de dichas sociedades mercantiles intervenga en la comisión de uno de los delitos del art.320 CP, es obvio que no respondería directamente como autores y/o partícipes de los mismos. Ahora bien, sí podrían depurarse responsabilidades penales a personas físicas, si se demostrara que concretos empleados de una sociedad mercantil que, por ejemplo, hubiera contratado con la Administración, estuvieran vinculados a ésta por alguno de los títulos del art. 24.2 CP y, en el ejercicio de funciones públicas en urbanismo u ordenación del territorio, cometieran uno de los tipos del art. $320 \mathrm{CP}$.

Así pues, a efectos de delimitar la referencia normativa a los funcionarios públicos (art.24.2 CP), del art.320.1 CP, no solo habrá que comprobar la posesión del título habilitante que permita el acceso a la condición funcionarial (art.103 CE), sino, ante todo, el requisito material o efectiva intervención en la función pública. Y, a tal efecto, para aplicar el art.320.1 CP, será imprescindible comprobar que determinado funcionario o autoridad, tenía encomendadas competencias para informar o inspeccionar en materia de urbanismo y/u ordenación del territorio. Y, además - respecto a ambos delitos- ha de probarse que, en el momento de los hechos, el funcionario se encontraba

70 Se alude allí a las sociedades mercantiles que ejecuten políticas públicas o presten servicios de interés económico general que sí pueden ser sancionadas con las penas del art.33.7 a) y g) CP. 
-o, cuanto menos, debía haber estado-, en el ejercicio de sus funciones. No obstante, la delimitación de lo que, en tiempos recientes, sea la función pública se torna polémica a medida que se ha producido una aproximación entre las actividades públicas y privadas. Y puesto que en el ámbito urbanístico e inmobiliario operan, con frecuencia, personas físicas y jurídicas privadas que, de forma habitual, prestan servicios a administraciones públicas (v.gr. como entidades colaboradoras), se plantea la capital cuestión de cuándo aquellas personas -0 incluso los empleados de entidades jurídicas privadas-participan del ejercicio de funciones públicas.

Con relación al art.320.1 CP, dicha problemática es trascendental porque habrá que determinar si pueden considerarse funcionarios públicos, quienes por cuenta propia o perteneciendo a un ente privado, ejercen funciones de asesoramiento técnico, o de información o de inspección en nombre o para la Administración que ha de conceder las licencias urbanísticas, a que allí se alude. Ante todo, porque cada vez, con mayor frecuencia, en urbanismo -debido a la imposibilidad de aumentar recursos y personal-, se habilitan a sujetos o entes privados para ejercer las funciones de información e inspección. Un problema común a este respecto es si los expertos, asesores independientes o técnicos contratados puntualmente por la Administración para realizar informes de licencias o incluso visar proyectos pueden considerarse "funcionarios" a efectos penales según el art.24 CP. Y, en especial, quienes realizan las inspecciones de dichas licencias o cualquier otra inspección a que se estuvieran obligados en urbanismo. Pues bien, como se ha avanzado, hay que admitir que son funcionarios a los efectos del art.320.1 CP, aquellos interinos, así como el personal con contrato laboral al servicio de la Administración, e incluso a los asesores técnicos independientes vinculados a la Administración mediante contrato de servicios o de consultoría siempre que sean ellos los que materialmente realicen los informes. Y además siempre que su vinculación se ajuste a lo previsto en el art.24.2 CP, es decir, cuando lo sean por disposición de ley o nombramiento de 
autoridad y, en efecto, ejerzan una función pública. Piénsese a tal efecto, que esta será la situación de muchos arquitectos y aparejadores por cuenta propia que, puntualmente o durante un periodo de tiempo, son nombrados como cargos municipales, con el fin de realizar informes. Con todo, la cuestión más polémica en este ámbito es dilucidar si los empleados de los Colegios profesionales que visan los proyectos técnicos (art.47.1 RDU) que acompañan al proyecto jurídico en el expediente urbanístico de concesión de licencia (art.4.2 RDU) y tienen capacidad de denegar un visado (arts. 46 y 47 RDU), entrarían dentro del círculo de sujetos activos del art.320.1 CP. Es decir, si a estos sujetos se les atribuye la condición de "funcionarios públicos" ex art.24.2 CP. En esta cuestión, me decanto por entender que el facultativo que realiza dicha actividad (por lo general los arquitectos de los correspondientes colegios profesionales) no ejerce funciones públicas. De un lado, porque difícilmente se podrá demostrar que aquellos empleados de colegios profesionales cumplen con el requisito formal o título habilitante que -no lo olvidemostambién se requiere a los efectos del art.24.2 CP. Y en todo caso, no se verifica el requisito material o participación en el ejercicio de la función pública, por la razón expuesta. ${ }^{71}$ Ante todo porque el visado es preceptivo para el proyectista y el solicitante de licencia, pero en ningún caso es vinculante para la decisión que debe adoptar el Ayuntamiento acerca de la concesión de licencia. Por todo ello entiendo que no pueden ser considerados funcionarios públicos a los efectos del art.24.2 CP. ${ }^{72}$ No obstante,

71 Más aún, la denegación de dichos visados por razones urbanísticas no impide solicitar y obtener la correspondiente licencia municipal, pues la Corporación municipal la otorgará o no "..a la vista de cuantos datos e informes obren en el expediente administrativo" (art.50.1 RDU). Por tanto, la carencia de dicho visado será, en su caso, causa de anulabilidad en la vía administrativa si la correspondiente legislación autonómica así lo prevé. Pero incluso puede suceder que el requisito del visado no se exija en una concreta normativa autonómica.

72 Vid. DE VICENTE MARTÍNEZ, R., "La responsabilidad penal del funcionario público o autoridad en materia de ordenación del territorio", Sanción penal y sanción administrativa en materia de ordenación del 
aunque el facultativo que emita un visado no pueda encajar en dicha categoría de sujeto activo y, por ende, no pueda ser autor de un delito del art.320.1 CP, nada impide que, en su caso, su contribución material como particular, pueda ser considerada a efectos de participación, necesaria (art.28 CP) o no necesaria (art.29 CP), en el delito del art.320.1 CP que cometa un funcionario o autoridad.

Por lo que toca al concepto penal de autoridad conforme al art.24.1 CP, se incluye-como es sabido-dentro del concepto penal de funcionario público. ${ }^{73} \mathrm{Y}$ ello porque la autoridad sería una especie del género funcionario. ${ }^{74}$ De las dos posibilidades que el art.24.1 CP prevé para conceptuar a la autoridad -tener mando o ejercer jurisdicción- parece claro que las autoridades a las que se refiere el art.320 $\mathrm{CP}$ han de ser aquellas que puedan reclamar obediencia, tanto en sus relaciones jerárquicas dentro de la Administración como con respeto a los ciudadanos. ${ }^{75} \mathrm{~A}$ tal efecto, cabrá considerar "autoridad", a miembros de las corporaciones locales, como alcaldes, tenientes de alcaldes (en especial cuando éstos ejercer de autoridad ${ }^{76} \mathrm{e}$ incluso, allí donde existan, alcaldes de barrio. En cuanto a concejales, la jurisprudencia ha estado dividida pues en algunas sentencias solo se les atribuye

territorio, Cádiz, 1997, págs. 182 y 183. VERCHER NOGUERA, A., La delincuencia urbanística. Aspectos penales prácticos sobre urbanismo y ordenación del territorio. Madrid, 2002, .pág. 160. Vid. GÓRRIZ ROYO, E., Los delitos de prevaricación...Op.cit.págs. 260 a 263. Cfr. SANTANA VEGA, D., "Artículo 320" en Comentarios al Código penal. Reforma LO 1/2015 y LO 2/2015 (dirs. CORCOY BIDASOLO/MIR PUIG), Valencia, 2015, pág.1152. Cfr. GÓMEZ TOMILLO, M., "Artículo 320" en Comentarios prácticos al Código penal, t. IV, $1^{\text {a }}$ ed., 2015, Pamplona, pág. 56.

73 Vid. GONZÁLEZ CUSSAC, J.L., El delito de prevaricación...Op.cit. pág.98.

74 Vid. DÍAZ Y GARCÍA CONLLEDO, M., voz "Autoridad y funcionario ..." Op.cit.pág. 180.

75 Vid. JAVATO MARTÍN, A.M., "El concepto de funcionario y autoridad..." Op.cit.pág. 168.

76 Vid. GÓRRIZ ROYO, E., Los delitos de prevaricación...Op.cit.pág.104. 
la condición de funcionario y, en otras, además la de autoridad. ${ }^{77}$ A mi modo de ver, ha de reconocérseles la condición de "autoridad", ${ }^{78}$ así como también a otros representantes elegidos democráticamente, como, por ejemplo, los diputados provinciales. Con respecto a los delitos del apartado $2^{\circ}$ art. $320 \mathrm{CP}$, por lo general, será preciso que se demuestre que las autoridades tenían competencia, específicamente, para votar o resolver "la aprobación de instrumentos de planeamiento, parcelación, reparcelación, construcción o edificación o la concesión de licencias" urbanísticas o relativas a la ordenación del territorio. Además, ha de demostrarse que en el momento de la comisión del delito se encontraban en el ejercicio de sus funciones. En principio parece que, con más frecuencia, los delitos del apartado $2^{\circ}$ del art.320 CP serán cometidos por sujetos considerados "autoridad" a efectos penales, si bien no puede perderse de vista que la obligación general de inspeccionar recae, en primer término, en Alcaldes, salvo delegación de éste en otra/s persona/s de su equipo de gobierno, comisiones municipales u otros organismos públicos (v.gr. policía, Guardia Civil). En este sentido, las novedosas conductas del apartado $1^{\circ}$ del art.320 CP y referidas a silenciar con motivo de inspecciones o de omitir la realización de inspecciones de carácter obligatorio, pueden también ser cometidas por dichas autoridades.

\section{1.c) El sujeto activo "inspector" en las prevaricaciones} omisivas

Mención aparte merecen las cuestiones que, en la actualidad, se suscitan con respecto al sujeto activo de las llamadas "prevaricaciones omisivas" del art.320.1 CP. Como se ha indi-

77 Vid. JAVATO MARTÍN, A.M., "El concepto de funcionario y autoridad..." Op.cit.pág. 169.

78 No plantearía ninguna duda, desde la previsión legislativa de los "miembros de las Corporaciones locales" como sujetos pasivos del delito de atentado por la LO 7/2000 de 22 de diciembre, que aludía a ellos en el art.551.2 CP. Vid. GÓRRIZ ROYO, E., Los delitos de prevaricación...Op. y loc ult.cit. Tras la reforma de LO 1/2015, 30 de marzo, aquel delito de atentado se prevé en el art.550.3 CP. 
cado antes, son sujetos sobre los que recae la obligación de inspeccionar, pero la desatienden, cometiendo determinadas omisiones. La inspección es una función pública que puede correr a cargo de un alcalde, en cuyo caso no se plantean problemas para reconocerle a éste la consideración de autoridad a efectos penales (art.24.1 CP). Al margen de esos casos, las conductas omisivas del art.320.1 CP plantean la cuestión de si cabe considerar funcionarios públicos a efectos penales, a otros sujetos, en particular a los inspectores en materia de urbanismo, y también, en su caso, a los asesores técnicos o colaboradores con los que puedan contar y en quienes deleguen dicha función.

La regulación administrativa específica en inspección urbanística es, por lo general, de carácter autonómico y/o municipal, y en ella se conceptúa la inspección como una función pública. Además, en la regulación sobre la inspección desarrollada por la mayoría de Comunidades Autónomas, se reconoce al inspector la condición de agente de la autoridad. ${ }^{79}$ En consecuencia, allí donde tengan atribuida dicha

79 Por ejemplo, en la Ley 5/2014, de 25 de junio de la Generalitat Valenciana de Ordenación del Territorio, Urbanismo y Paisaje, el art.270 establece que (1)" La función inspectora será desarrollada, en el ámbito de sus respectivas competencias, por los municipios y por la Generalitat. (2). La realización de la inspección se realizará bajo la superior autoridad y dirección del órgano de gobierno que corresponda y será desempeñada por el personal al que se atribuya este cometido dentro de cada uno de ellos". (4) Las fuerzas y cuerpos de seguridad, en el ámbito de sus respectivas competencias, colaborarán con la función inspectora, prestando su auxilio cuando se les solicite. (5) El personal adscrito a la inspección urbanística tendrá la consideración de agente de la autoridad". El art.190.4 de la Ley del Suelo 9/2001, de 17 de julio, de la Comunidad de Madrid, establece que "en el ejercicio de sus funciones, los inspectores gozarán de plena autonomía y tendrán, a todos los efectos, la condición de agentes de la autoridad." El art. 190.2 de Ley 15/2001, de 14 de diciembre, del Suelo y Ordenación Territorial de Extremadura establece que “...los funcionarios de la Comunidad Autónoma de Extremadura que, en sustitución de los Municipios o, en su caso, en concurrencia con los mismos, realicen funciones de inspección tendrán la condición de Inspectores Territoriales." En concreto: "El Inspector Territorial tiene, en el ejercicio de sus funciones, la consideración de agente de la autoridad". 
condición, ${ }^{80}$ los inspectores también podrán integrar el círculo de sujetos activos de los delitos del art.320.1 CP, pues en todo caso, son funcionarios públicos a efectos penales que ejecutan las decisiones de la autoridad. ${ }^{81}$ Por otra parte, puede darse que la función inspectora se asuma por otros funcionarios considerados autoridad a efectos penales (v.gr. determinados miembros de las fuerzas de seguridad del Estado), que, asimismo, podrían devenir autores conforme al art. 320.1 CP.

Un escenario distinto que suscita dudas, sería el de los casos en que dichos inspectores puedan ser asesorados o tengan colaboradores en asuntos técnicos, pues se plantea si éstos pueden ser considerados funcionarios públicos conforme al citado art.24.2 CP. Junto a este supuesto cabe traer a colación, por otra parte, el caso en que el inspector en materia urbanística realice un acto de delegación de funciones - por cualquier método de gestión ( $v . g r$. concesión, contratación)- de modo que la acción de inspeccionar se realice, en realidad, por particulares por cuenta propia o pertenecientes a organismos privados. En estos últimos supuestos ¿pueden considerarse a dichos sujetos, funcionarios a efectos penales?

Para enfocar esta cuestión hay que partir de analizar si el título habilitante de los colaboradores, asesores y las personas en las que se delegue, sería bien el nombramiento por parte de la autoridad competente, bien un contrato temporal o eventual. Si esto es así, los colaboradores y asesores pueden ser considerarlos funcionarios públicos a efectos del art.320.1 CP siempre que, además y, aunque sea temporalmente, ejerzan funciones públicas consistentes en asesorar y colaborar con el inspector que es el que, finalmente, ha de firmar el acta de inspección. Esto sen-

80 Probablemente con ello los legisladores autonómicos tratan de ofrecer una protección a través del delito de atentado, resistencia y desobediencia a la autoridad.

81 Como destaca JAVATO MARTÍN, en ausencia de precepto legal, la doctrina y la jurisprudencia ha venido caracterizando a los agentes de la autoridad como aquellos funcionarios públicos encargados de ejecutar las decisiones de la autoridad, en ““"El concepto de funcionario...” Op.cit.pág. 170. 
tado, habrá que dilucidar si la contribución material que el asesor o colaborador haya aportado -que, al menos formalmente, no sustituye al inspector-, permite hablar de un caso de participación en el delito del inspector. Por otra parte, la delegación de la inspección es una situación, a mi entender, distinta pues consiste en remitir en bloque dicha función pública a otra persona (v.gr. empleados por cuenta propia o sobre organismos con estructuras privadas) que, por lo general, se convertirá en el responsable último de la inspección. Si el "delegado" es nombrado por título habilitante como tal o contratado en tales términos, habrá que atender además si efectivamente ejerce la función pública inspectora, de modo que, si incluso tiene competencia para firma el acta de inspección, y así lo hace, cometiendo un delito del art. 320.1 CP, parece evidente que puede responder como autor.

En todo caso, el dato fundamental para determinar si se participa o no del ejercicio de la función pública, será si la Administración -estatal, autonómica o local- aparece como responsable última, directa o indirectamente, de la actividad delegada -en especial, como responsable civil subsidiaria-, por cuanto ostentaba su titularidad. ${ }^{82}$ Si conforme a los anteriores parámetros se concluye aceptando que, en el caso concreto, el sujeto que omite una inspección con relevancia penal ex art.320.1 CP, ostenta la cualidad de funcionario público a efectos penales, cabrá admitir su condición de autor de este delito. Y ello incluso aunque no posea dicha condición a efectos administrativos. Si, por el contrario, en dicho supuesto se concluye que, a quien se le ha encomendado, por delegación, alguna actividad inspecto$\mathrm{ra}$, no ostenta la condición de funcionario público conforme al art.24.2 CP, podrá valorarse si su intervención se reputa cooperación necesaria ${ }^{83}$ o complicidad (art.29 y $63 \mathrm{CP}$ ) en alguno de los delitos en que una autoridad o funcionario sea autor.

82 Vid. VALEIJE ÁLVAREZ, I., "Reflexiones...” Op.cit.pág.492.Vid. GÓRRIZ ROYO, E., Los delitos de prevaricación...Op.cit.pág.98.

83 Vid. GÓRRIZ ROYO, E., Los delitos de prevaricación...Op.cit.págs.138 y 139. 


\subsection{Prevaricaciones del apartado $1^{\circ}$ del art. $320.1 \mathrm{CP}$}

En el apartado $1^{\circ}$ art.320 CP se castigan hasta tres modalidades alternativas de conducta típica, a saber: a) informar favorablemente instrumentos de planeamiento, proyectos de urbanización, parcelación, reparcelación, construcción o edificación o la concesión de licencias contrarias a las normas de ordenación territorial o urbanística vigentes; b) silenciar la infracción de dichas normas, con motivo de inspecciones; c) omitir la realización de inspecciones de carácter obligatorio.

La novedosa previsión de las modalidades omisivas es tributaria de la reforma penal de 2010 que, además, amplió los ámbitos donde se castiga la acción de informar favorablemente $\mathrm{y}$, en coherencia con ello, las de votar y resolver a favor. Interesa, por tanto, analizar cada una de estas modalidades de conducta en particular.

5.2.a) Prevaricaciones consistentes en "informar favorablemente" y remisión en blanco

Como se ha destacado, tras la reforma de LO 5/2010, el ámbito típico de esta conducta se ha ampliado considerablemente ${ }^{84}$ pues ahora se extiende no sólo a los proyectos de edificación y a la concesión de licencias -como sucedía originariamente en el CP de 1995-, sino también a los "instrumentos de planeamiento, proyectos de urbanización, parcelación, reparcelación, construcción o edificación.” En realidad, la acción típica es la misma en todos aquellos casos, pues se sustancia en "informar favorablemente". Pero en atención a los objetos sobre los que recae dicha acción, la misma puede revestir diversas peculiaridades. Por eso, a efectos interpretativos, cabe distinguir tres grupos de conductas: 1) aquellas consistentes en informar proyectos 2) la relativas a informar la concesión de licencias y, por último,

3) la referida a informar otros instrumentos de planeamiento.

84 Vid. VILLACAMPA ESTIARTE, C., "Delitos sobre la ordenación del territorio y el urbanismo (arts. 319 y 320 CP)" en La Reforma Penal: análisis y comentarios (dir. Quintero Olivares) Cizur Menor, 2010, pág.281. 
Para todas aquellas modalidades de conducta, el acto de "informar" ha de interpretarse en el mismo sentido, es decir, como el acto de trámite del órgano consultivo competente, que no manifiesta un contenido decisorio y, por ello mismo, no constituye en sí una resolución administrativa (como, por otra parte, sí se exige en el art.404 CP). ${ }^{85}$ Informar consistirá, por tanto, en ofrecer una opinión profesional, es decir, como experto, sobre la puesta en marcha de una actuación -en este caso, de índole urbanística- de modo que se valora la oportunidad o viabilidad de la misma. Pero no se decide definitivamente acerca de su efectiva realización. Por otra parte, en algunos casos de informes, cabe incluso que el emisor simplemente suscriba un dictamen previo o que se adhiera al de otro, mediante la consignación de una "nota de conformidad". ${ }^{86}$ Pese a las anteriores diferencias, el informe comparte una nota común con la resolución administrativa, en cuanto a la función que ambas desempeñan puesto que, grosso modo, puede calificarse de control preventivo previo.$^{87}$ En consecuencia, ambos actos pueden prevenir conductas contrarias a la legislación del suelo, si bien la decisión definitiva $o$ decisoria al respecto solo se puede adoptar mediante una resolución.

Frente a estos actos administrativos, actualmente, la Administración también puede realizar actuaciones de control "posterior" al inicio de una actividad con incidencia en la ordenación del territorio, como son las inspecciones y las comunicaciones. Es importante diferenciar todas estas actuaciones administrativas, pues la mayoría de ellas tienen reflejo en una conducta delictiva del art.320 CP. Centrándonos en el informe, hay que precisar que sus características formales no están tasadas

85 Vid. GÓRRIZ ROYO, E., Los delitos de prevaricación urbanistica, ... Op.cit.pág. 227.

86 Vid. GÓMEZ TOMILlo, M., “Articulo 320”, Comentarios al Código penal, $2^{a}$ ed., 2011, p. 1252.

87 Es decir, son actuaciones administrativas que se emiten antes de la efectiva realización de la actividad sometida a opinión o decisión por parte del órgano administrativo. 
en el art.320.1 CP, de modo que, en principio, cabe admitir tanto los escritos como los orales. Tampoco existen límites formales respecto a los destinatarios de los informes, pues el precepto no indica si han de ir dirigidos a otros funcionarios y/o autoridades de la misma Administración que el que informa o de una distinta. En consecuencia, habrá que considerar típico cualquier informe, con independencia del destino que tenga.

Así delimitada la acción típica de informar, se hace más patente que el delito del art.320.1 CP referido a esta conducta, es de mera actividad. Es decir, no se precisa más que la simple acción de informar a favor, sin resultado ulterior, para apreciar la tipicidad de la conducta. Así lo ha admitido el TS, entre otras, en la Sentencia de 7 de julio de 2014, FD $4^{\circ}$ (TOL4.443.383), donde se confirma la condena por un delito del art.320.1 CP, a un arquitecto técnico municipal que "... emitió informes favorables contrarios a la norma aplicable, con pleno conocimiento de tal irregularidad." En la misma, se ratifica "el carácter de delito de mera actividad, que se consuma con la sola emisión de tales informes, sin necesidad de que éstos den lugar a resolución administrativa alguna.." (FD $4^{\circ}$ ). Al margen de estos rasgos comunes, el delito del apdo. $1^{\circ}$ art.320 CP ha ampliado notablemente el ámbito de la responsabilidad funcionarial por vía de añadir proyectos y, en especial, al incluir la referencia expresa a instrumentos del planeamiento, sobre los que puede recaer la conducta típica, por la que el posible autor -por lo general, funcionario técnico-, puede incurrir en responsabilidad penal. ${ }^{88}$

1) Con relación a los informes relativos a determinados proyectos y a la concesión de licencias, a que se refiere el apdo. $1^{\circ}$ art.320 CP ha de recordarse que tienen lugar en la primera fase de la tramitación del procedimiento conducente a otorgar una licencia. ${ }^{89}$ No obstante caben, en realidad, dos modalidades de conducta:

88 A este respecto, con carácter general, vid. GÓRRIZ ROYO, E., en Comentarios a la reforma penal de 2010, Valencia, 2010, pág. 378 y ss.

89 Vid. GÓRRIZ ROYO, E, Los delitos de prevaricación urbanística...Op.cit. p. 229. 
1.a) En primer lugar, la acción de informar a favor de proyectos de urbanización, parcelación, reparcelación, construcción o edificación. En primer lugar, los proyectos de urbanización son proyectos de obras, sin contenido planificador, que tiene por objetivo urbanizar -y no edificar- ${ }^{90}$ bien concretando en la práctica las directrices del planeamiento general en suelo urbano, bien poniendo en marcha las determinaciones del planeamiento de desarrollo en suelo urbanizable. Serían herramientas para aplicar lo que disponga el planeamiento (v.gr. en materia de abastecimiento de agua o alcantarillado $)^{91}$. Por lo que respecta al resto de proyectos previstos en el art. 320.1 CP, están relacionados con el proceso de otorgamiento de licencias, dado que suelen ser los instrumentos que, dependiendo del tipo de obra, integran el llamado expediente de concesión de licencias que se compone del informe técnico y jurídico y la propia solicitud de una licencia. Así, los proyectos de parcelación aluden a la actividad de parcelar, esto es, a la acción consistente en modificar la forma o linde de una o varias parcelas, o dividir simultánea o sucesivamente los terrenos en dos o más lotes o fincas, cuando pueda dar lugar a la construcción de un núcleo de población. ${ }^{92} \mathrm{Su}$ previsión parece adecuada atendiendo a consideraciones de proporcionalidad y siempre que se enfoque la intervención penal hacia las parcelaciones ilegales más graves, en atención a la legislación de cada territorio. Por lo que respecta a los proyectos de reparcelación, se refieren a la actividad distinta a la anterior y por lo general de entidad menos grave ${ }^{93}$. En esencia,

90 Vid. GÓMEZ TOMILLO, M. quien remite a la STS 663/2005, de 23 de mayo, en "Artículo 320" en Comentarios al Código penal, 2011...Op.cit. pág. 1253.

91 Valoran como acertada la previsión de los proyectos de urbanización, POMARES CINTAS, E./BERMEJO CHAMORRO, A.J., dada su potencialidad lesiva, en “¿Era necesario reformar los delitos urbanísticos?”... Op.cit.pág. 138.

92 Este es el entendimiento que se deriva del art.94.1 del Texto refundido de la Ley de Suelo de 1976. Vid. GÓRRIZ ROYO, E. Protección penal ...Op. cit, págs. 1081-1082.

93 Vid. POMARES CINTAS, E./BERMEJO CHAMORRO, A.J., "Era necesario reformar los delitos urbanísticos..." Op. cit.pág. 140. 
consistiría en agrupar lotes o fincas comprendidas en un perímetro de ejecución sistemática que puede ser, por ejemplo, un polígono. Y ello con el fin de proceder a su nueva división ajustada al planeamiento, de modo que se puedan adjudicar las parcelas resultantes a los correspondientes interesados, de manera proporcional a los derechos que ostenten sobre aquellas fincas. ${ }^{94}$ Una característica relevante de la reparcelación es que se sustancia en un instrumento jurídico de carácter público, cuyo objetivo es favorecer la ejecución del planeamiento.

Por lo que toca a los proyectos de construcción, en general, su previsión viene a introducir mayor coherencia, frente a la escueta referencia -antes de 2010- a los proyectos de edificación. La diferencia entre ambos ha de establecerse, partiendo de la distinción entre la actividad más genérica de "construir" y la más específica de "edificar" en términos penales. Así pues, los proyectos de construcción se referirán a cualquier obra que incorpore al suelo, elementos físicos permanentes con los que, por lo general, se modifica la naturaleza del terreno. ${ }^{95}$

Los proyectos de edificación ya estaban previstos en el art.320.1 CP antes de 2010, y, por tanto, han de seguir definiéndose como proyectos técnicos más específicos en tanto dirigidos principalmente, a la realización de obras mayores de nueva planta destinadas a la habitación, morada, reunión o vivienda de las personas. ${ }^{96}$ Como se observa, frente al anterior art.320.1 CP, la reforma de 2010 ha ampliado la acción típica de este delito mediante las referencias, a los proyectos de urbanización, parcelación, reparcelación y construcción, con las que se incorporan conductas más graves que la relativa a informar proyectos de

94 Vid. v.gr. el régimen previsto en el art.42 y 43 de la Ley extremeña 15/2001, de 14 de diciembre, del Suelo y Ordenación Territorial.

95 Vid. GÓRRIZ ROYO, E., Protección penal de la Ordenación..Op.cit. pág. 851 .

96 Vid. GÓMEZ TOMILlO, M., Urbanismo, Función pública y Derecho penal, Granada, 2000, pág. 104. Vid. GÓRRIZ ROYO, E., Los delitos de prevaricación urbanística ...Op.cit.pág. 235. 
edificación -lo que merece una valoración positiva ${ }^{97}$-, toda vez que la intervención penal se expande en esta materia, pues ahora alcanza a ilícitos que, antes de 2010, no eran delictivos.

1.b) En segundo lugar, con respecto a la acción de informar la concesión de licencias urbanísticas, por lo general, se tratará de licencias de obras, de modo que éstas se interpretan, a efectos penales, como actos administrativos cuyo informe previo es preceptivo. En relación con ello, hay que tener en cuenta que el art. 9.1.1 RSCL ${ }^{98}$ establece que las solicitudes de licencias “..se presentarán en el Registro general del Ayuntamiento, y si se refieren a ejecución de obras o instalaciones, deberá acompañarse proyecto técnico con ejemplares para cada uno de los organismos que hubieren de informar la petición." A ello hay que añadir que el 4.2 RDU ${ }^{99}$, establecen que "...en todo expediente de concesión de licencia constará informe técnico y jurídico..." 100

El requerimiento preceptivo de los informes favorables, garantiza mejor la ofensividad de estas conductas, puesto que los mismos tienen un carácter obligatorio que evidencia una mayor lesividad. ${ }^{101}$ Por el contrario, entiendo que rara vez dichos informes serán vinculantes, salvo disposición expresa que obli-

97 Vid. GÓMEZ TOMILLO, M., “Artículo 320” en Comentarios prácticos ... 2015, Op. cit. pág.57.

98 Decreto de 17 de junio de 1955, por el que se aprueba el Reglamento de Servicios de las Corporaciones Locales.

99 Real Decreto 2187/1978, de 23 de junio, por el que se aprueba el Reglamento de Disciplina Urbanística para el desarrollo y aplicación de la Ley sobre Régimen del Suelo y Ordenación Urbana.

100 Y ello siempre que: “...la Entidad otorgante cuente con los servicios correspondientes o le sea posible contar con los de la Entidad comarcal o metropolitana en que esté integrada. Si la Diputación Provincial tuviese establecido servicio de asistencia urbanística a los Municipios, podrá solicitar el Ayuntamiento informe del mismo, si no contase con servicios técnicos o jurídicos propios". En todo caso, recuérdese que en el mismo art. 4 apartado $1^{\circ} \mathrm{se}$ establece que "el procedimiento de otorgamiento de las licencias se ajustará a lo establecido en la legislación de Régimen Local."

101 Vid. GÓRRIZ ROYO, E., Los delitos de prevaricación urbanistica.... Op.cit. págs. 229 y 230. 
gue a que tengan dicho carácter. Como ya sucedía conforme a la anterior redacción del art.320.1 CP, durante la fase en que el funcionario competente realice el informe sobre dicha solicitud, puede incurrir en responsabilidad penal. Ahora bien, si bajo el anterior texto la doctrina dudaba acerca de si la licencia había de referirse a todos o solo algún acto o uso del suelo, ${ }^{102}$ en atención al nuevo art.320.1 CP parece que pueda admitirse que el control penal recaiga sobre la solicitud de licencia relativa a cualquiera de dichos actos, dado que en general se ha ampliado la intervención en este ámbito. ${ }^{103}$ Además, en la actualidad el art.11.4 a) del Real Decreto Legislativo 7/2015, de 30 de octubre, considera que los actos de edificación (como movimientos de tierras, explanaciones, parcelaciones, segregaciones u otros actos de división de fincas en cualquier clase de suelo, y la reparcelación) requerirán "..acto de conformidad, aprobación o autorización administrativa que sea preceptivo, según la legislación de ordenación territorial y urbanística, debiendo ser motivada su denegación". ${ }^{104}$

No obstante, puede limitarse dicha intervención exigiendo que sólo sea susceptible de sanción penal, las solicitudes de licencia urbanística que, al menos, incurran en infracción grave o muy grave de las normas urbanísticas y de ordenación del territorio. Por consiguiente, no cabrá admitir la tipicidad de la conducta consistente en informar obras menores, sobre todo si, como sucede por lo general, esta clase de obras, queda sujeta, a la mera comunicación.

2) Informe de instrumentos de planeamiento, es decir, cualquier plan urbanístico o relativo a la ordenación del terri-

102 Entre otros previstos en el derogado art.178. 1 del Texto refundido del Suelo de 1976 y el vigente art.1 RDU, cabe citar: movimientos de tierras, excavaciones, parcelaciones urbanas, modificación de estructuras, demoliciones, etc..

$103 \mathrm{La}$ inclusión de todos estos proyectos, actos y usos de suelo susceptibles de ser informados, podría estar relacionada con la introducción, en el art. 319 $\mathrm{CP}$, de la referencia a "obras de urbanización" tratando así el legislador de coordinar el ámbito de aplicación de ambos preceptos.

$104 \mathrm{Vid}$. Real Decreto Legislativo 7/2015, de 30 de octubre, por el que se aprueba el texto refundido de la Ley de Suelo y Rehabilitación Urbana. 
torio susceptible de ser aprobado en ejercicio de la potestad de planeamiento. De ordinario, esta potestad corresponde a los municipios, pero no sólo a ellos, pues, en ocasiones, puede ser necesaria la intervención de administraciones autonómicas. De este modo se estaría dando entrada al castigo, en concepto de prevaricaciones, de supuestos no relacionados estrictamente con el proceso de otorgamiento de licencias, sino con el de aprobación de cualquier plan de ordenación del suelo. ${ }^{105} \mathrm{Y}$ en consecuencia, de forma novedosa, el Derecho penal puede intervenir, en los términos previstos en esta prevaricación del art.320.1 CP, en los procesos de clasificación del suelo ${ }^{106}$-desarrollados tras la entrada en vigor de la reforma penal de 2010 - y que tantas dificultades han planteado a la hora de desentrañar tramas de corrupción urbanística.

$\mathrm{Al}$ respecto, y dado que el art. $320 \mathrm{CP}$ no hace más especificaciones, podrán incluirse toda clase de planes, aprobados por las diversas administraciones territoriales. Es decir, tanto planes generales de ordenación urbana, como otros instrumentos relativos a los planes de desarrollo (planes parciales de ordenación, planes especiales), bien hayan sido informados a favor por la Administración municipal, bien por la autonómica. Asimismo, pueden incluso subsumirse en este precepto, los llamados estudios de detalle. ${ }^{107}$ Ahora bien, lo que no puede subsumirse en este precepto es la conducta de informar, votar o resolver una

105 Por esta vía, parece que se podría intervenir penalmente en la adopción de informes relativos a todo tipo de planes y a los procesos de reclasificar y recalificar el suelo y el territorio.

$106 \mathrm{Ha}$ de diferenciarse entre las funciones de "clasificar" el suelo (entre urbano, urbanizable y no urbanizable) y "calificar" el suelo. Así, reclasificar es cambiar una clase de suelo por otra (v.gr. se cambia el destino de suelo no urbanizable a urbanizable; o de suelo urbanizable a urbano); mientras que recalificar consiste en alterar el uso al que estaba destinado el terreno. Vid. POMARES CINTAS, E./BERMEJO CHAMORRO, A.J., “¿Era necesario...” Op.cit.pág.135.

107 Vid. GÓMEZ TOMILLO, M., “Artículo 320” en Comentarios prácticos... Op.cit.pág.57. 
revisión del planeamiento municipal ${ }^{108}$, pese a ser una de las actividades más comúnmente vinculadas a actuaciones corruptas.

Al margen de estos planes, se plantea una cuestión respecto a la acción de "informar" pues cabe la duda de si puede ir referida las llamadas comunicaciones previas y, en ese caso, si cabría su castigo. En puridad, se plantea la cuestión de si un funcionario o autoridad puede cometer prevaricación urbanística en relación con las llamadas comunicaciones previas introducidas a raíz de la trasposición al ordenamiento jurídico español de lo dispuesto en la Directiva de Servicios (en adelante, DS), por virtud de la acción combinada de la Ley 17/2009, de 23 de noviembre ${ }^{109}$ y la Ley $25 / 2009$, de 22 de diciembre. ${ }^{110}$ Ante todo porque la mayoría de Comunidades Autónomas han introducido las comunicaciones en sus respectivas legislaciones para así evitar el otorgamiento de licencias urbanísticas sobre todo si las obras que se pretenden realizar, son de las calificadas como menores. ${ }^{11}$

Para mejor abordar esta cuestión, es preciso retomar el análisis del capital elemento normativo previsto en la estructura típica del delito del art.320.1 CP. Me refiero a la novedosa remisión en blanco, que - desde 2010 - alude a la infracción de "normas de ordenación territorial" junto a la ya existente exigencia de infracción de las normas urbanistica vigentes. Estamos ante reenvíos normativos que permiten afirmar que en el art.320 CP se contiene una ley penal en blanco. Concretamente a través de ella se establece una accesoriedad de derecho, en relación con todo el Derecho administrativo urbanístico y de ordenación del

108 Vid. VILLACAMPA ESTIARTE, C., "Delitos sobre la ordenación..." Op.cit.pág. 283.

109 Ley 17/2009 de 23 de noviembre, sobre el libre acceso a las actividades de servicios y su ejercicio. También denominada "Ley paraguas".

110 La Ley 25/2009 de 22 de diciembre, de modificación de diversas leyes para su adaptación a la Ley sobre el libre acceso a las actividades de servicios y su ejercicio, es conocida como "Ley ómnibus".

111 Por ejemplo, el art. 172 de la LSOTE de 2001, prevé el régimen de la comunicación previa para el ámbito de la Comunidad Autónoma de Extremadura. 
territorio, que envía a un amplio campo externo al Derecho penal. Y, a la vez, permite una mayor flexibilidad y adaptación de este precepto a los cambios que tengan lugar en dicha normativa administrativa llamada a integrar el art. $320 \mathrm{CP} .{ }^{112}$ Como puede advertirse el ámbito de reenvío es muy amplio por cuanto no solo atañe a la legislación de la ordenación del territorio sino también a la regulación urbanística local. En efecto, con ello, se da por cerrado "ex lege" un complejo debate doctrinal anteriormente planteado, ${ }^{113}$ acerca de qué normas -además de las urbanísticas- podían o no ser incluidas en este precepto. ${ }^{114} \mathrm{Y}$ además se amplía considerablemente el campo del reenvío al extenderse a más normas del sector administrativo, que pueden incluso ser de rango autonómico y local. Por lo que respecta al objeto de este estudio, dicha remisión normativa plantea diversas cuestiones, en particular, si cabe incluir las normas que en el ámbito local permiten sustituir la exigencia de licencia de obras por la de comunicación previa.

De un lado, no cabe duda que la ley estatal del Suelo, así como las respectivas leyes del Suelo autonómicas y las normas urbanísticas municipales tendrán cabida en aquella remisión normativa. Pero también, y desde la reforma penal de 2010, cualquier norma estatal, autonómica y local referida a la "ordenación del territorio". Se plantea, además si, merced la referencia a "normas urbanísticas", cabe subsumir en ellas las "normas del planeamiento". En otro lugar, me manifesté a favor de que así fuera, ${ }^{115}$ por cuanto los planes tienen, técnicamente,

112 A diferencia de ello, otras remisiones normativas son más rígidas o estáticas. Por ejemplo, considérese la remisión previstas con respecto a las prevaricaciones ambientales del art.329.1 CP

113 Vid. VILLACAMPA ESTIARTE, C., "La accesoriedad del Derecho penal frente al Derecho administrativo: criterios de imputación penal en el delito urbanístico" en Studia Iuridica, año 2008, n²3, págs. 181 a 185.

114 En la redacción del art. 320 CP, anterior a 2010, no se aludía a las normas de ordenación territorial. Vid. GÓRRIZ ROYO, E, Delitos de prevaricación urbanistica...Op.cit.pág.179 y ss.

115 Vid. GÓRRIZ ROYO, E, Protección penal de la ordenación del territorio... Op.cit.pág. 882. 
naturaleza normativa (vid. STS 17 de octubre de 1998, Sala $3^{\text {a }}$, $\mathrm{FJ} 2^{\circ}$ ) y rango de reglamentos, subordinados a las leyes de las que traen causa, de modo que forman parte del ordenamiento jurídico (vid. STC 56/1986, de 13 de mayo, FJ $4^{\circ}$ ). ${ }^{116}$ Sin embargo, solo los "planes" propiamente dichos, tiene carácter normativo y no así los proyectos de urbanización, los proyectos de delimitación del suelo urbano y los catálogos. Por tanto, solo aquellos planes en sentido estricto podrían subsumirse en la remisión del art.320 CP. ${ }^{117}$ Por lo que toca al contenido de las normas a las que se alude con esta remisión, en efecto, la nueva referencia a las "normas de ordenación del territorio" disipa ahora las dudas, a favor de que se puedan también incluir las normas relativas al llamado suelo "no urbanizable de especial protección" o categorías equivalentes. ${ }^{118}$

De otro lado, esta amplia remisión normativa plantea la duda - antes apuntada- acerca de si, las llamadas "comunicaciones" son susceptibles de la acción tipificada en el art. 320.1 $\mathrm{CP}$, es decir, si pueden ser "informadas" en contra de la legislación vigente relativa a la ordenación del territorio o del urbanismo. Pues bien, inicialmente, parece difícil que dicha hipótesis se pueda verificar y, por tanto, castigar semejantes conductas, pues ello plantearía tanto un problema de legalidad, ${ }^{119}$ como la imposibilidad de compatibilizar el significado y contenido de

116 De modo que contienen un conjunto de normas que delimitan los derechos y deberes de los propietarios de los predios (vid. STS de 3 de marzo de 1980, Sala $3^{\mathrm{a}}$ ).

117 Vid. GÓMEZ TOMILLO, M., “Artículo 320” en Comentarios prácticos ... Op.cit.pág. 1257.

118 Vid. MARTÍNEZ BUJÁN PÉREZ, C., Derecho penal Económico y de la empresa, $5^{\mathrm{a}}$ ed., Valencia, 2015, pág. 924.

119 Es decir, a pesar de que el legislador penal de 2010 podía haberse hecho eco de alguna de las novedades introducidas por la aludida DS, no previó ninguna alusión a las "comunicaciones previas". De modo que, formalmente en el tipo penal del art. 320.1 CP no tienen cabida las comunicaciones, pues, entenderlas incluidas, comportaría una aplicación analógica contra reo de la ley penal, proscrita desde los postulados de la legalidad penal y presunción de inocencia. 
la acción de "informar" con la de "comunicar." Ante todo porque el funcionario al que se dirige la comunicación, más que "informar" simplemente ha de "dar conocimiento de.." 20 Y ello porque las comunicaciones no son actos de control preventivo previo -como las licencias- sino que desempeñan un papel de verificación posterior.

Unido a lo anterior, ha de repararse en que el requisito de la infracción de las normas urbanísticas o de ordenación del territorio al que alude el art.320.1 CP no siempre y necesariamente ha de constituir un delito -v. gr. uno de los del art.319 $\mathrm{CP}-$ sino que puede ser una infracción administrativa. $\mathrm{Y}$ ello porque -como ya se ha destacado- a diferencia del art.329.1 CP, el art.320.1 CP solo requiere la contrariedad o infracción de normas urbanísticas o de ordenación del territorio. Es decir, como se critica en la doctrina penal, formalmente cabe subsumir en este precepto, cualquier conducta allí descrita, sin discriminación alguna por razón de su gravedad. ${ }^{121}$ Frente a esta técnica legislativa, cabe oponer que, de un lado, el carácter de "ultima ratio" del Derecho penal obliga, a adoptar una interpretación restrictiva en cuanto a la gravedad de dichos ilícitos, toda vez que, de otro, el dato de que el precepto contemple una prevaricación, impone comprobar la "arbitrariedad" de la conducta, ${ }^{122}$ lo que, asimismo, excluye el castigo de meras ilegalidades. En consecuencia, las infracciones que quepa incluir en la remisión en blanco del art. $320 \mathrm{CP}$, al menos, han de revestir carácter grave o muy grave cuando no constituir un delito. Así pues, se excluiría del ámbito típico, la comisión de infracciones urbanisticas me-

120 Para ello habrá que estar a la concreta legislación urbanística vigente en cada nivel territorial, que, por lo general, considera las comunicaciones previas de los interesados como un acto de trasmisión de conocimiento (en ningún caso de contenido resolutorio) y que -como también se indicó-, en escasas ocasiones, antes del inicio de la actividad, se fiscaliza por un funcionario público.

121 Vid. la acertada objeción de GÓMEZ RIVERO, C., "Ilegalidad urbanística: acerca de los límites entre el injusto penal...” Op.cit.pág. 14

122 Vid. POMARES CINTAS, E./BERMEJO CHAMORRO, A.J., “¿Era necesario reformar los delitos urbanísticos?...” Op.cit.pág. 130 y 131. 
nos graves y las leves como presupuestos para aplicar alguno de los delitos del art.320 CP. ${ }^{123}$ Esta interpretación adquiere mayor coherencia si cabe, desde la previsión en el orden administrativo de las llamadas "comunicaciones". Porque, algunas infracciones menos graves y, por lo general, las infracciones leves van referidas a obras menores, de modo que dichas obras ya no suelen ser susceptibles de licencia, sino de comunicación. Cuando así suceda, aquellas infracciones menores quedaran excluidas del ámbito típico del art.320.1 CP. Sentada esta restricción interpretativa, habrá que orientar la aplicación de los delitos del art. 320 $\mathrm{CP}$ hacia casos en que se compruebe una infracción administrativa grave o muy grave de la legislación de ordenación del territorio o urbanismo, o, en todo caso, si se demuestra la comisión de un delito del art.319 CP. ${ }^{124}$ No obstante, para un sector de la doctrina penal, solo en estos últimos casos cabría aplicar el delito del art. 320.1 CP. ${ }^{125}$

Aun asumiendo el criterio cuantitativo como divisoria principal entre ilícitos y delitos urbanísticos, es evidente que la escasa o nula coordinación entre los órdenes penal y administrativo para evitar solapamientos normativos, hace que la ofensividad respecto del bien jurídico "ordenación del territorio" que manifiestan muchas infracciones urbanísticas graves o muy graves y los delitos del art.319 CP, no sea muy dispar. Asimismo, lo cierto es que, en ninguna de las sucesivas reformas penales, el legislador ha considerado oportuno condicionar la comisión del delito del art. $320 \mathrm{CP}$ a la de algún delito del art.319 CP, a modo de "delitofin". En consecuencia, lo único que queda fuera de duda es que el

123 Vid. GÓRRIZ ROYO, E., Delitos de prevaricación urbanistica...Op.cit. págs. 207 a 213.

$124 \mathrm{Si}$ conforme al criterio restrictivo expuesto, las infracciones concernientes a licencias de obras menores, no pueden integrar la remisión del art.320.1 $\mathrm{CP}$ y, además normalmente, son estas licencias las que se sustituyen por comunicaciones previas, ello implica que formalmente las infracciones referidas a las comunicaciones, por su escasa entidad, no podrán subsumirse en el precepto penal.

125 Vid. MARTÍNEZ BUJÁN PÉREZ, C., Derecho penal Económico...Op.cit. pág. 923. 
art.320.1 CP no puede aplicarse si solo se demuestran infracciones leves o muy leves (o categorías equivalentes) de las normas urbanísticas o de ordenación del territorio. Sirvan algunos ejemplos para explicar esta toma de posición. En el caso del funcionario público que emite un informe a favor de determinado proyecto de parcelación urbanística (u obra de construcción), algunas leyes autonómicas, ${ }^{126}$ requieren licencia urbanística previa. $\mathrm{Si}$ dicho informe a favor, se realiza por el funcionario técnico a sabiendas de que la parcelación es manifiestamente contraria al ordenamiento jurídico urbanístico, pues se va a llevar a cabo en suelo no urbanizable, la parcelación contenida en dicho proyecto verificaría el requisito del art.320.1.1 CP de ser "contrarias a las normas de ordenación territorial o urbanística vigentes." Pero es que, además, la parcelación en sí sería una infracción urbanística muy grave según prevén algunas leyes autonómicas. ${ }^{127}$ Asimismo, sería complejo deslindar dicho ilícito, del injusto del actual art.319.2 CP. Y la conducta del funcionario que informa a favor de dicha parcelación ilícita y a sabiendas de su injusticia, podría subsumirse en el ámbito típico del art.320.1.1 CP. En segundo lugar, supongamos que un particular pretende realizar un acto de parcelación conforme a la legislación y el planeamiento urbanísticos, pero sin efectuar la comunicación previa requerida. Esta conducta puede ser calificada, en algunos casos, de infracción urbanística leve (vid. v.gr. art. 215 h) del TRLU. Cat. 2010 (en su reforma por Ley 3/2012, de 22 febrero) ${ }^{128}$. Sin embargo, nunca podría, en mi opinión, subsumirse en el delito

126 Vid. art. 187 b) de Decreto Legislativo 1/2010 de Cataluña, de 3 de agosto (TRLU. Cat.2010) por el que se aprueba el Texto refundido de la Ley de urbanismo.

127 Vid. art. 213 a) del TRLU. Cat. 2010 (Texto Refundido de la Ley urbanística de Cataluña). Vid. art. 246.2 de la Ley 5/2014, de 25 de julio, de la Generalitat, de Ordenación del Territorio, Urbanismo y Paisaje, de la Comunitat Valenciana, donde se califican de "infracciones muy graves": las parcelaciones ilegales en suelo pendiente de programación o respecto al que el planeamiento no autorice su urbanización.

$128 \mathrm{En}$ otras leyes autonómicas, las infracciones leves se definen más genéricamente en tanto se refieren a ejecutar obras o instalaciones sin licencia y orden de ejecución, pero son legalizables por ser conforme al ordenamiento urbanístico. Vid. art. 246.4 de la Ley 5/2014, Comunidad Valenciana. Tampoco esta clase de ilícito podría integrar la contravención a la que alude el art.320.1 CP. 
del art.320.1.1 CP, por carencia de lesividad exigida para constituir ilícito penal. Además, por la propia dinámica de la acción cometida (particular que parcela sin comunicarlo previamente) no es necesario la intervención de funcionario alguno que emita un informe, como requiere la literalidad del art.320.1.1 CP, de modo que, en ningún caso, éste sería aplicable.

Pese a que por vía interpretativa se puede restringir la aplicación del art. 320.1 CP a casos de infracciones administrativas graves o muy graves, sería conveniente que dicha limitación constara en el tenor literal del precepto, a través de una exigencia expresa de la gravedad de la contravención o términos equivalentes, en el mismo sentido en que en el art. 329.1 CP se alude a manifiestamente ilegales.

\section{2. b. Prevaricaciones omisivas}

$\mathrm{El}$ art.320.1 CP alberga, merced una importante modificación en este precepto introducida por la LO 5/2010, dos modalidades de conducta omisivas estrechamente vinculadas a la inspección urbanística. Ambas se refieren a la función pública de control "ex post" consistente en inspeccionar. La mayor relevancia de la función administrativa de inspección en los últimos tiempos, se evidencia al hacerse eco de ella la mayoría de legislaciones autonómicas del suelo. ${ }^{129}$

Las nuevas modalidades de conducta omisivas, consisten, respectivamente, en silenciar la infracción de normas relativas a la ordenación del territorio o urbanísticas, con motivo de inspecciones y omitir la realización de inspecciones de carácter obligatorio.${ }^{130}$ Con ello se equiparan las modalidades omisivas

129 Considérese v.gr. art. 164 de la Ley 15/2001, de 14 de diciembre, del Suelo y Ordenación Territorial de Extremadura; art. 201 del Texto Refundido de la LU.Cat. 2010; art. 269 y ss de la Ley 5/2014, de 25 de julio, de la Generalitat Valenciana.

130 Con ello, no solo se igualan las modalidades del delito del apdo. $1^{\circ} \mathrm{del}$ art.320 CP con las de la prevaricación en medio ambiente del art.329.1 ${ }^{\circ}$ $\mathrm{CP}$ sino que incluso se amplía el ámbito típico de ambas, al introducir la última modalidad de conducta omisiva citada supra. Vid. GORRIZ ROYO, E., Comentarios a la reforma penal...Op.cit.págs. 380 y 381. 
de este precepto a las del art.329.1 $\mathrm{CP},{ }^{131}$ toda vez que se agrava considerablemente la responsabilidad de funcionarios y autoridades con competencias en urbanismo. ${ }^{132}$ Así pues, a raíz de la reforma penal de 2010, parece haber prevalecido la opción de castigar estas conductas omisivas por encima del mantenimiento de una estructura en dos apartados del art.320 CP que refleje fielmente las distintas partes del proceso de concesión de licencias y otros instrumentos urbanísticos. En todo caso, la previsión de modalidades omisivas ha supuesto una interesante novedad en el contexto de la corrupción urbanística, de ahí que sea importante abordar su interpretación, analizando por separado cada una de las modalidades de conducta típicas.

b.1.- La previsión de la primera modalidad de conducta omisiva del art.320.1 CP consistente en silenciar infracciones, había sido demandada por una parte de la doctrina penal especializada. ${ }^{133}$ Entre otros aspectos, su previsión implica que ahora los funcionarios con competencias en la inspección quedan incluidos en el círculo de sujetos activos de este delito especial. Concretamente la conducta requeriría demostrar que concurre la siguiente situación típica: a raíz de una inspección, el funcionario competente para realizarla, ha de presenciar la comisión de una infracción urbanística; si bien, finalmente ha de probarse que dicho funcionario no da cuenta de ella, por ejemplo al

131 Vid. GÓRRIZ ROYO, E., "Omisión y tolerancia administrativa en el derecho penal del medio ambiente, a propósito del art.329.1.2 ${ }^{\mathrm{a}}$ CP" en Revista de Derecho y Proceso penal, año 2005-2, nº 14, págs. 25 y ss.

132 Una posible causa de la inicial ausencia de castigo del silencio de infracciones con motivo de la inspección urbanística en el art. 320.1 del original CP de 1995, podría haber sido que, por lo general, la inspección en materia urbanística queda fuera del procedimiento administrativo de concesión de licencias. Es decir, la intervención de los funcionarios y autoridades con competencias inspectoras se produce con posterioridad a las fases tipificadas en los iniciales delitos del art.320 C.P. y por ende, el castigo expreso de aquellas conductas podía trastocar la división de aquel precepto, en dos apartados.

$133 \mathrm{Vid}$. dichas demandas doctrinales, en GÓRRIZ ROYO, E., Los delitos de prevaricación...Op.cit.pág. 220 y nota al pie nº 436. 
no hacerla constar cuando levante el correspondiente acta de inspección. ${ }^{134}$ Cabe entender que esta figura delictiva se dirige a castigar, exclusivamente, una conducta omisiva, para lo que habría que partir del significado del verbo típico esto es, de una interpretación gramatical, de modo que la acción contenida en el verbo silenciar significaría "callar, omitir, pasar en silencio." 135 Teniendo presente estas definiciones del término "silenciar", cabe advertir que en el inciso segundo del art.320.1 CP, se contiene una directiva de conducta implícita u obligación de informar, que, compele a poner de manifiesto o, por mejor decir, a denunciar las infracciones de las leyes o disposiciones normativas reguladoras de las licencias de funcionamiento, en medio ambiente. De modo que el castigo del funcionario o autoridad que silencia se fundamenta no tanto en la alteración de la realidad que puede realizar, cuanto en el incumplimiento de aquel deber de informar de las infracciones que presencie. Asimismo, de lo anterior cabe deducir que, entre otros supuestos excluidos del ámbito típico de esta modalidad de conducta se encontrarían los casos en que se incumplieran las tareas de inspección -si se estuviera obligado a realizarla-, y también se excluirían los supuestos de "absentismo en la inspección." Y ello sin perjuicio de que, como a continuación veremos, a partir de la reforma penal de 2010, estas omisiones pueden subsumirse en la siguiente modalidad omisiva del art.320.1, 2 CP.

b.2.- Es más evidente con respecto a la segunda modalidad de conducta, que se castiga una pura inactividad sin resultado ulterior, al consistir en la mera omisión de realizar inspecciones de carácter obligatorio. Ahora bien, parece que con la incriminación de esta conducta el Derecho penal habría llegado demasiado lejos. Y ello porque se trataría de castigar conductas que son puros incumplimientos formales de la normativa admi-

134 Vid. GÓRRIZ ROYO, E., “Omisión y tolerancia administrativa ...” en $R D P P, 2005-2, \mathrm{n}^{\circ} .14$, pág.47.

135 Primera acepción del verbo silenciar en DRAE (edición digital: www.drae. es). 
nistrativa. Esto es, se ampliaría el castigo a la mera omisión de quien, estando obligado a inspeccionar, deja de hacerlo, sin exigir un ulterior resultado, es decir, con independencia que de ello se derive alguna infracción administrativa -grave o leve-, delito urbanístico, o incluso nada. Pese a que esta modalidad omisiva pudiera haberse incluido para garantizar el cumplimiento de la función inspectora y no burlar la posible responsabilidad penal por el anterior ilícito omisivo del art.320.1, 2 CP, ${ }^{136}$ simplemente abandonando aquella función por quien está de servicio, tampoco esta justificación salva el evidente déficit de lesividad que el delito manifiesta. Ante todo, porque, inicialmente, para verificarlo no sería preciso demostrar la ofensa a bien jurídico alguno, simplemente bastaría con el incumplimiento formal de la obligación de inspección. Esta interpretación literal puede ampliar tanto el ámbito de aplicación del precepto que es necesario restringirla en atención, entre otros, a los principios de proporcionalidad, ultima ratio y presunción de inocencia. ${ }^{137} \mathrm{Y}$ en ese sentido, habría que exigir que las inspecciones omitidas permitieran teleológicamente la comisión de, cuanto menos, infracciones urbanisticas graves.

Esto sentado, ha de repararse en que estas modalidades omisivas del art.320.2 CP, tienen aún más restringido su ámbito típico por razón del sujeto activo. Así solo podrá cometerse por un sujeto cualificado - funcionario público o autoridad- que, además, tenga competencia en la especifica función pública de inspeccionar en materia de ordenación de territorio o urbanismo. Y que estuviera obligado a ejercerla en el momento de la comisión

136 Vid. VILLACAMPA ESTIARTE, C., "Delitos sobre la ordenación del territorio..” Op.cit.pág. 284-285.

137 No obstante, según la circular 7/2011, de la Fiscalía (pág.1782) parecen proclives a aplicar este delito, entre otras, la sentencia de 19 de abril de 2010 del Juzgado de lo Penal número 7, de Málaga, el Juzgador, después de condenar al autor de una construcción ilegal, condena igualmente al Alcalde-Presidente de la Corporación dado que el mismo «tenía la obligación legal de velar por el cumplimiento de la legalidad urbanistica en el territorio de su Municipio...». 
del aquellos ilícitos. Para constatar dicha competencia, habrá que acudir a la normativa de las correspondientes CCAA e incluso a la normativa local. Es esencial por ello delimitar brevemente esta función en urbanismo que, por otra parte, es una actividad administrativa básica en ordenamientos jurídicos que potencian, prima facie, una eficaz prevención de ilícitos administrativos.

\section{2.c) En especial, la inspección urbanística}

En primer lugar, ha de destacarse que la inspección es una función o potestad pública, ${ }^{138}$ de modo que, desde el punto de vista administrativo, consiste, materialmente, en obtener información, comprobar, examinar, vigilar o investigar cualesquiera hechos, actos, actividades, situaciones, documentos, etc. que sean "debidos". ${ }^{139}$ Junto a este concepto, aquella función puede delimitarse conforme a determinados rasgos, ${ }^{140}$ también denominados elemento objetivo, ${ }^{141}$ subjetivo ${ }^{142}$ y normativo. ${ }^{143}$ Dichos rasgos suelen predicarse de la inspección en tanto se dirige a alcanzar dos objetivos principales. Éstos consistirían en

$138 \mathrm{La}$ inspección se atribuye a la Administración e inequívocamente requiere el ejercicio de un imperium. Vid. BERMEJO VERA, J., "La administración inspectora", El Derecho administrativo en el umbral del s.XXI, tomo I, Valencia, 2000, pág.1256. Según AMENÓS ALAMO, J., cualquier clase de inspección simboliza dominio, en La inspección urbanística: concepto y régimen jurídico. Barcelona, 1999, pág.32.

139 Dichos actos son aquellos que los diferentes sujetos estén, de forma positiva o negativa, obligados a realizar de la manera determinada en las leyes y los reglamentos. Vid. GÓRRIZ ROYO, E., "Omisión y tolerancia administrativa en Derecho penal del medio ambiente, ...” Op.cit. pág.29.

140 Vid. AMENÓS ALAMO, J., La inspección..Op.cit.págs.42 a 44.

141 Ello implica, en primer término, que la inspección es una actividad de reconocimiento que requiere una observación directa o contacto inmediato con la realidad verificada.

142 En segundo lugar, la inspección implica una facultad, pues el inspector ejerce un poder público sobre sujeto/s pasivo/s vinculado/s al objeto o actividad sometida a verificación, que tiene/n obligación de permitir y facilitar la comprobación.

$143 \mathrm{Al}$ inspector le asiste, en tercer lugar, la prerrogativa de reclamar conocimiento o aumento de datos. 
lograr información sobre un supuesto que pueda subsumirse en una norma jurídica y dar cuenta de ello al órgano competente para resolver lo oportuno -elemento teleológico-. Por todo ello se le reconoce además una finalidad preventiva de ulteriores infracciones. En todo caso, por último, la actividad inspectora debe "formalizarse" en cuanto la información obtenida ha de plasmarse en escritos, que pueden ser "actas, denuncias o diligencias".

De entre las notas indicadas, destaca una posible finalidad de la inspección, en tanto puede servir para preparar una reacción administrativa ante eventuales incumplimientos, de suerte que, puede admitirse que la inspección por sí sola cumple una función preventiva, siendo siempre auxiliar o instrumental de otras. Dicho auxilio se dirige, en concreto, al posible ejercicio de la potestad sancionadora. No obstante, la eventual reacción sancionadora frente a posibles incumplimientos ya no forma parte de la inspección, a la vez que esta función pública cumple con algo más que con una tarea auxiliadora pues, por ejemplo, puede ser empleada para prevenir riesgos o para restablecer la legalidad o asegurar intereses generales. ${ }^{144}$ Teniendo presente estos fines, el inspector puede adoptar una serie de medidas que, según el derecho administrativo, no tienen carácter sancionador y que suelen describirse en las legislaciones autonómicas o locales. ${ }^{145}$ Junto a estas posibles medidas, conviene reparar en la otra finalidad de la inspección, cual es, obtener determinada información de interés para la Administración, de modo que la misma tiene valor probatorio, como una prueba más, en los correspondientes procedimientos. ${ }^{146}$

144 Vid. REBOLLO PUIG, M., "La actividad inspectora" en La función inspectora, INAP, Madrid, 2013, págs.58.

145 Por ejemplo, piénsese, en la posibilidad de suspender una licencia.

146 Según REBOLLO PUIG, M., concederle dicho valor a la inspección no comporta dar a los documentos donde se plasman los datos o información obtenida, una presunción de veracidad, ni un valor probatorio privilegiado, sino que se incorpora como una prueba más "sin necesidad de ratificación ..”, en "La actividad inspectora” Op.cit.págs.66 y 100. 
Esto sentado con respecto a la función pública de inspeccionar en urbanismo, a mi modo de ver, las dos conductas omisivas del art. $320.1 \mathrm{CP}$-y sobre todo la segunda- habrían de ir referidas solo a los casos más serios, para no vulnerar el carácter de última ratio del Derecho penal. Es decir, se aplicarían en casos en que lo que se omite son, cuanto menos, infracciones urbanisticas graves o muy graves. Ello impediría aplicar este delito en los casos en que se lleven a cabo actuaciones sin la preceptiva comunicación previa pues -según vimos-, el incumplimiento de su regulación suele originar, de ordinario, infracciones leves (vid. así v.gr. art. 215 h TRLUrb.C. 2010). Por todo ello, ha de orientarse la aplicación de este delito a casos de incumplimiento de la obligación de inspeccionar que afecte a los dos bienes jurídicos tutelados en este precepto, esto es, la ordenación del territorio y el correcto funcionamiento de la Administración urbanística como servicio a los ciudadanos. De manera que, dicho incumplimiento impidiera conocer la comisión de, al menos, infracciones urbanísticas muy graves, cuando no de un delito urbanístico. Ahora bien, pese a dicha interpretación restrictiva, lo cierto es que la segunda modalidad omisiva, esto es, la consistente en omitir la realización de inspecciones de carácter obligatorio, sigue planteando déficit de ofensividad difícilmente salvables, porque formalmente permite la intervención penal a casos de meros incumplimientos de la normativa administrativa referida a la obligación de inspección. Por ello, ante la palmaria vulneración de principios penales, como el de presunción de inocencia y proporcionalidad, que este entendimiento comporta y en coherencia con las exigencias de "injusticia" y "arbitrariedad" en todos los delitos del art. $320.1 \mathrm{CP}$, sería lo conveniente que el propio precepto exigiera la prueba de que, con aquel incumplimiento de la obligación de inspeccionar, se favoreció, cuanto menos, la comisión de una infracción muy grave bien de la normativa urbanística, bien de la de ordenación del territorio.

Como conclusión al análisis de las prevaricaciones del apartado $1^{\circ}$ art. $320 \mathrm{CP}$, cabe destacar que se dirigen a atajar gran parte de la corrupción que se gesta en el ámbito urbanístico, por 
cuanto la misma interfiere y manipula el proceso de concesión de licencias urbanísticas o el de aprobación de planes de ordenación territorial. Y aun cuando las prácticas corruptas se extienden también a la gestión y contratación en la actividad urbanística, al menos este precepto blinda la mayoría de fases del procedimiento de concesión de licencias que, por lo general, es el que genera efectos económicos más directos y a corto plazo. ${ }^{147}$ Añadido a los anteriores delitos, la vigente legislación penal, castiga a las autoridades y funcionarios que, a sabiendas, votan o resuelven arbitrariamente a favor de determinados actos administrativos, como seguidamente se analizará.

5.3. Prevaricaciones urbanisticas consistentes en resolver y votar a favor: el apartado $2^{\circ}$ del art.320 CP

El análisis de las prevaricaciones del apartado $2^{\circ}$ del art.320 CP ha de empezar advirtiendo que la mayoría de requisitos típicos analizados del art. $320.1 \mathrm{CP}$ han de aplicarse, asimismo, a los delitos de este precepto, en especial, la interpretación que haya de hacerse de la remisión en blanco, así como de los instrumentos de planeamiento, los proyectos de urbanización, parcelación, reparcelación, construcción o edificación o la concesión de las licencias. ${ }^{148}$

La referencia a estos instrumentos del planeamiento, proyectos y licencias, se introdujo conforme a la LO 5/2010 de 22 de junio. Dichas alusiones expresas han de ser valoradas muy positivamente de modo que así se corrige una imperfección técnica de la redacción que databa de 1995, conforme a la que el apartado $2^{\circ}$ del art. $320 \mathrm{CP}$, no aludía específicamente al objeto de lo resuelto o votado (sólo se hacía referencia genérica a "su concesión"). Ello dio lugar a diversas dudas que, desde la citada reforma penal de 2010, fueron despejadas por el legislador en el

147 Vid. en sentido próximo POZUELO PÉREZ, en "La respuesta penal.." Op.cit.págs. 73 y 74.

148 Vid. GÓRRIZ ROYO, E., Delitos de prevaricación urbanística, Op.cit. pág. 179 y ss.; pág. 207-212. 
sentido de entender que el objeto de lo que se vota o resuelve son solo los instrumentos del planeamiento, proyectos y licencias a que alude el art.320.2 CP. Al propio tiempo, no puede ignorarse que, con las referencias explícitas a instrumentos del planeamiento, proyectos de urbanización, parcelación, reparcelación o construcción, se ha ampliado notablemente el ámbito típico propio de los delitos del art.320.2 CP. Y ello porque las acciones típicas previstas en este precepto, pueden recaer sobre un mayor número de instrumentos y proyectos, si bien siguen consistiendo en votar o resolver a favor. Son conductas que, por lo general, se cometerán, de manera alternativa.

Así, por "resolver" cabe entender la misma acción típica del art.404 CP, de modo que será "cualquier acto administrativo que suponga una declaración de voluntad, de contenido decisorio, que afecte a los derechos de los administrados y a la colectividad en general, bien sea expresa o tácita, escrita u oral" (vid. STS n1 460/2002, de 16 de marzo, FD $2^{\circ}$ ). Esta conducta puede albergar tanto tomas de decisiones individuales como colectivas. En este último caso la resolución será, por lo general, la decisión adoptada tras un proceso de votación. Parece por tanto claro que esta última modalidad de conducta puede calificarse de prevaricación en sentido estricto. Y esa es, precisamente, la segunda modalidad de conducta prevista en el art. 320.2 CP que consiste en "votar" a favor. En atención a la misma, cabe dar por superados los problemas que plantean casos de abstención, voto nulo o en blanco, pues al exigirse un voto en sentido afirmativo, solo estas conductas serán punibles. ${ }^{149}$ Es decir, el sentido de "votar"

149 No obstante, doctrinalmente, se sigue discutiendo en relación con otras hipótesis, como votos en contra, en blanco o nulos cuando con ellos se contribuye materialmente a conformar una votación a favor en el seno de órganos colegiados y, por ende, pueden suponer una contribución siquiera indirecta al delito del art.320.2 CP. Vid. VILLACAMPA ESTIARTE, C., "Delitos sobre la ordenación..." Op.cit.pág. 281. A mi entender, los límites de la legalidad penal impiden castigar dichas formas de votar, pues no son expresamente a favor. Vid. GÓRRIZ ROYO, E., Los delitos de prevaricación... op.cit.pág. 281. Vid. MUÑOZ CONDE, F., Derecho Penal Parte Especial, $20^{\mathrm{a}}$ ed., Op.cit.p. 290. 
o "resolver", necesariamente han de ser “a favor" de modo que se excluye la tipicidad de las conductas consistente en votar y resolver en contra, o votar de forma nula o en blanco. Una de las conclusiones más importantes es que aquella votación o resolución en sentido efectivamente positivo ha de conectarse con la nueva alusión a instrumentos del planteamiento, proyectos de urbanización y licencias que ahora se indican en el apartado $2^{\circ}$ del art.320 CP. Así, desde la entrada en vigor de la reforma penal de 2010 pueden calificarse de delictivas las votaciones o resoluciones arbitrarias con que se aprueben un planeamiento. Y también pueden considerarse delitos la votación y resolución a favor de proyectos que en el apartado $2^{\circ}$ se indican, además de las licencias urbanísticas que, asimismo, sean susceptibles de ser consideradas arbitrarias e injustas; siempre que, en todos estos casos, pueda demostrarse además la concurrencia de dolo. En ello consiste el efecto expansivo de la tipicidad pues ahora cabe castigar casos muy controvertidos, como son los de planificación del suelo. Sin embargo, nótese que tiene una limitación temporal, pues solo podrá aplicarse en referencia a hechos acaecidos, con posterioridad a 2010.

Con respecto a la nueva referencia a todos estos actos administrativos, en especial, a las "licencias" hay que tener en cuenta lo ahora previsto en la reciente Ley 39/2015, de 1 de octubre, del Procedimiento Administrativo Común de las Administraciones Públicas (que deroga la Ley 30/1992), en su Título III, Capítulo I relativo a los actos administrativos, su contenido (art.34), producción (art.35), motivación (art.34) y forma (art.36) en especial, por lo que toca a la posibilidad de que sean escritos o verbales. También conviene retener que conforme al art.22.2 c) ${ }^{150}$ de la vigente Ley 7/1985, de 2 de abril, reguladora de la Bases del Régimen Local, corresponde al Pleno municipal en los Ayuntamientos, y a la Asamblea vecinal en el régimen

150 Precepto reformado por la Disposición Adicional Novena del Real Decreto Legislativo 7/2015, de 30 de octubre, por el que se aprueba el texto refundido de la Ley de Suelo y Rehabilitación Urbana. 
de Concejo Abierto, las atribuciones de “...la aprobación inicial del planeamiento general y la aprobación que ponga fin a la tramitación municipal de los planes y demás instrumentos de ordenación previstos en la legislación urbanística, así como los convenios que tengan por objeto la alteración de cualesquiera de dichos instrumentos".

En consecuencia, los miembros del Pleno municipal o, en su caso, de la Asamblea vecinal, entrarían dentro del círculo de sujetos activos del delito del art.320.2 CP en tanto, encargados de votar o resolver la aprobación de dichos planes. Sin embargo, no podrían devenir autores -por falta de castigo expreso de la conducta- si la acción consistiera en votar o resolver a favor de la aprobación de "convenios" que tengan por fin alterar cualquier plan o instrumentos del planeamiento. También quedarían fuera del ámbito típico las llamadas revisiones del planeamiento pese a que pudiera votarse o resolverse a su favor, de manera arbitraria y "a sabiendas" de su injusticia. Ni, por último, parece posible considerar delictivas las conductas de votar a favor o resolver "comunicaciones previas" pues por la propia naturaleza y procedimiento de realización de las mismas no necesitan ni ser "votadas" ni ser "resueltas", y por tanto su inclusión en el art.320.2 CP vulneraría el principio de legalidad penal y de ofensividad. Si bien no hay nada que objetar a esto último, ha de criticarse que queden excluidas del ámbito típico, conductas relativas a votar o resolver arbitrariamente a favor de revisar planes o aprobar convenios que pudieran alterar instrumentos y planes urbanísticos, a sabiendas de su injusticia. De ahí que sería conveniente una reforma en el sentido de prever expresamente dichas conductas.

Por otra parte, ha de destacarse la similitud entre los delitos del art. $320.2 \mathrm{CP}$ y algunas infracciones administrativas autonómicas, ${ }^{151}$ lo que podrá plantear problemas de bis in ídem,

151 Téngase en cuenta por ejemplo el apartado $4^{\circ}$ del art.198 de la Ley 15/2001, del Suelo de Extremadura. 
a la hora de evitar duplicidad de sanciones administrativas y penales. ${ }^{152}$

Por lo demás, respecto a las conductas del apartado $2^{\circ}$ art. $320 \mathrm{CP}$, han de darse aquí por reproducidas las consideraciones realizadas anteriormente en referencia al apartado $1^{\circ}$ art.320 $\mathrm{CP}$, con respecto a la interpretación de la exigencia de arbitrariedad-derivada de la infracción de las normas de ordenación del territorio y urbanísticas vigentes- y de la prueba de la comisión "a sabiendas de su injusticia". No obstante, seguidamente, se analizará con más detalle la exigencia del dolo en relación con el elemento subjetivo de este tipo, por la importancia que su prueba está adquiriendo en sede judicial.

Con respecto al iter criminis de estos delitos del apartado $2^{\mathrm{o}}$ art.320 CP y, en concreto, en referencia a la consumación, como ya se ha avanzado, ésta tendrá lugar en el momento en que se haga efectivo el voto o la resolución favorable. Así pues, la consumación de los delitos del apartado $2^{\circ}$ art.320 CP, no está supeditada a un ulterior resultado, como por ejemplo podría ser que el concreto plan urbanístico, proyecto o licencia surta efectos. Parece evidente que estamos ante delitos de mera actividad y por tanto basta votar o resolver a favor, sin necesidad de probar ningún eventual resultado como consecuencia de aquella acción. Tampoco será, por tanto, preciso demostrar que la licencia efectivamente ingresó en el tráfico jurídico, ni siquiera que se iniciaran las obras amparadas en dichas licencias, proyectos o instrumentos. ${ }^{153}$ En su caso, todo ello podrá considerarse a efectos del agotamiento del delito. En consecuencia, sería difícil admitir la tentativa acabada de estos delitos pues es complejo

152 No obstante, el art. 231 de la misma Ley 15/2001, establece las reglas de "prejudicialidad" que prácticamente consagran la preferencia de la jurisdicción penal en materia de infracciones y sanciones urbanísticas.

153 Vid. ROMEO CASABONA, C./SOLA RECHE, E./BOLDOVA PASAMAR, M.A. (coords.) en Derecho penal. Parte Especial. Granada, 2016, pág. 546. Cfr. SANTANA VEGA, D., en "Artículo 320" en Comentarios al Código penal. Reforma LO 1/2105 y LO 2/2015, (dirs. CORCOY BIDASOLO, M./ MIR PUIG, S.) Valencia, 2015, p. 1154. 
imaginar un supuesto en que se inicie una votación a favor y ello no constituya ya consumación del delito; o se empiece a resolver a favor -por escrito u oralmente- y no esté ya consumado el delito. Teóricamente, sin embargo, cabrá admitir la tentativa inacabada en supuestos muy excepcionales en que, por ejemplo, se anuncie el previo voto a favor, pero finalmente no haya constancia formal de ello o se vaya a resolver a favor, pero un tercero lo interrumpa e impida materialmente. Con todo, la punición de estos casos dependerá de la prueba de los elementos subjetivo y objetivo de la tentativa, lo que en la práctica dificultará su efectivo castigo.

Por último, respecto a la autoría y participación en estos delitos, el círculo de posibles autores se cierra considerablemente por la referencia a funcionarios públicos y autoridades, que habrán de interpretarse en los términos del art.24 CP. Dado el carácter de delitos especiales propios de los tipos del art.320 CP, en caso de que para su comisión se identifiquen otros intervinientes que sean particulares, al no reunir la condición de estos sujetos cualificados, podrán ser considerados, en su caso, partícipes en el delito que ahora nos ocupa atendiendo, como es obvio, a la contribución material que realicen (vid. arts. 28 y 29 CP), pudiéndose atenuar la pena que corresponda al cooperador necesario o al inductor, en los términos previstos en el art. 65.3 CP.

5.4. Especial referencia al elemento subjetivo: la STEDH de 8 marzo 2016

Entre los requisitos comunes a todos los delitos del art.320 CP, destaca la exigencia de dolo y, vinculado a ello, el requisito comúnmente entendido como un elemento subjetivo del tipo y que, según doctrina mayoritaria, se identifica con la referencia típica "a sabiendas". Al margen ahora de la controversia doctrinal con respecto a la función de dicho elemento como requisito añadido o derivado del dolo, a efectos prácti$\cos$, la consecuencia que sin duda cabe extraer de su exigencia, es que no puede castigarse la modalidad imprudente de estos 
delitos. ${ }^{154}$ Es decir, respecto de todas las prevaricaciones rige la exigencia de la prueba del dolo, quedando excluidas del ámbito penal las conductas imprudentes que, en su caso, habrán de depurarse por vía administrativa. A lo anterior hay que añadir que el requisito del elemento subjetivo del tipo referido a "a sabiendas" ha de interpretarse en relación con la exigencia de la "injusticia" y de la arbitrariedad de la conducta, aspecto este último que, en el contexto de los delitos del art.320 CP, ha de probarse a raíz de la contrariedad a las normas de ordenación del territorio o urbanísticas vigentes. Es decir, ha de demostrarse una contravención arbitraria, lo que implica que, cuanto menos sea una infracción grave o muy grave de las normas urbanísticas o de ordenación del territorio y el autor ha de ser perfectamente consciente de dicha arbitrariedad. La prueba de este aspecto dificultará, por tanto, cualquier comisión que no sea con dolo directo.

Así pues, el dolo del autor abarcará todos los aspectos concernientes a la arbitrariedad del informe, así como, en su caso, de las omisiones tipificadas en el apartado $1^{\circ}$ art. $320 \mathrm{CP}$ o de la resolución o votación del apartado $2^{\circ}$. Las dudas acerca de la prueba del dolo de uno de los delitos del art. $320 \mathrm{CP}$, han de resolverse a favor del reo, debiéndose probar, como cualquier otro elemento del delito, más allá de toda duda razonable. A tal efecto, considérese la STS 14 de diciembre 2016 (FD 2 ${ }^{\circ}$, TOL5.916.784), donde se ratifica la absolución precisamente por falta de demostración del denominado "elemento subjetivo". Con todo no hay que descartar supuestos en los que el castigo dependa de la prueba de un dolo eventual, diferenciándolos de situaciones de culpa consciente que, sin duda alguna, habrán de quedar impunes. Tampoco se aplicarán los delitos del art.320.1 y 2 CP si se aprecia un error de tipo (art.14.1 CP), pues sea éste vencible o invencible, por virtud del sistema de incriminación expresa de la imprudencia (art.12 CP), no se castigan los casos

154 Vid. MUÑOZ CONDE, F., Derecho penal. Parte Especial, $20^{\mathrm{a}}$ ed., Valencia, 2015, p. 490-491. 
de prevaricaciones urbanísticas en modalidad imprudente. Más aún, puesto que los delitos del art.320 CP exigen el requisito "a sabiendas", nuestro TS ha rechazado su castigo tanto cuando concurre el citado error de tipo, como el llamado error de prohibición (vid. STS 14 de octubre de 2014, FD 7º, TOL4.545.819).

Partiendo de esta evidencia, ha de destacarse la importancia que, en sede judicial, ha adquirido la prueba del llamado "elemento subjetivo del tipo", a efectos de decidir sobre la culpabilidad del acusado en casos de prevaricaciones urbanísticas. Hay que precisar, no obstante, que, en sede judicial, no se diferencia de forma suficiente entre el dolo y el elemento subjetivo del tipo relativo a "a sabiendas", de modo que, por lo general y de manera inexacta, se suelen unificar o confundir y, por tanto, su prueba se demuestra conjuntamente o sin diferenciar aquellos dos elementos del delito. Con todo y con ello, no puede obviarse la importancia del binomio dolo-elemento subjetivo del tipo previsto en el art.320 CP. Entre las sentencias que así lo ponen de manifiesto destaca sobremanera la STEDH de 8 de marzo de 2016 (demanda $\mathrm{n}^{\circ}$ 47530/13) que resuelve el llamado "Caso Porcel Terribas y otros contra España".

Como se adelantó, en esta sentencia se condena al Estado español por entenderse vulnerado el art.6.1 CEDH, como respuesta a la demanda de los condenados por la SAP de Granada de 28 de julio de 2011, Sección 1a, (TOL 2257174) por un delito del art.320.2 CP. Dicha sentencia revocó, en sede de revisión, la sentencia absolutoria, previamente dictada por el Juzgado de lo penal $n^{\circ} 3$ de Granada de 12 de julio de 2010. Interesa destacar que el juez de primera instancia consideró que, con relación a los mismos acusados -todos ellos concejales y, por tanto, autoridades a efectos penales-, no había quedado "... suficientemente acreditado la concurrencia del elemento intencional o subjetivo que precisa el tipo, (...) precisando, por tanto, dolo, es decir, intención deliberada y plena conciencia de la ilegalidad del acto realizado por lo que ha de acordarse la absolución de los mismos."

Dicha resolución fue recurrida por diversas acusaciones particulares y el Ministerio Fiscal, quien solicitó que se celebrara 
una vista para que la Audiencia, en sede de recurso de apelación, pudiera oír a los testigos que formularon su declaración ante el citado Juzgado de lo Penal $\mathrm{n}^{\circ}$ 3. No obstante, la AP de Granada, decidió que no era necesaria dicha audiencia, por cuanto, dicha jurisdicción de apelación entendió que no era competente para reproducir los medios de prueba correctamente practicados por el Juez de instancia. Pese a ello la SAP de Granada volvió a analizar la concurrencia del elemento subjetivo del art. 320.2 $\mathrm{CP}$, concluyendo que:

"...contrariamente con el criterio aplicado por el Juez a quo en la Sentencia ahora impugnada, la "ciega obediencia debida", "adhesiones inquebrantables" o el obrar "por motivos patrióticos" no son motivos que les eximan del elemento intencional o subjetivo...la admonición y advertencia formulada por escrito por parte del secretario general de la corporación y reiterada verbalmente, lleva a considerar que la conducta de los cuatro acusados citados, bien pudiera e indudablemente haber sido legalmente exigible otra muy distinta a la finalmente adoptada; ni una pregunta o cuestión o mínima duda, o propuesta de aplazamiento de la votación hasta saber del tenor del informe emitido o de su destino, salió de sus labios, cuando precisamente y como reza literalmente la Sentencia impugnada ahora "a lo anterior ha de sumarse que los cuatro acusados antes mencionados carecían de competencia en materia urbanística teniendo encomendadas otras parcelas del gobierno local (...)." $\left(\right.$ FD $\left.6^{\circ}\right) \cdot{ }^{155}$

155 En el mismo FD $6^{\circ}$ se indica que la condena solicitada para los acusados, como autores de la prevaricación urbanística del art.320.2 CP “...no se funda en una nueva valoración de sus declaraciones exculpatorias, o de las declaraciones de los coacusados y testigos, pues la cuestión se reduce a una controversia entre la interpretación del derecho, lo que conduce necesariamente a determinar que puede revocarse la sentencia absolutoria apelada y dictarse sentencia condenatoria en apelación por aplicación de distintos criterios puramente jurídicos y no de hecho y la prueba documental aportada puede valorarse en esta segunda instancia sin cortapisa alguna, dado que dicha valoración, en atención a la naturaleza de esa prueba en cuestión, no precisa de inmediación alguna." 
Sobre la base de este razonamiento y otras consideraciones ${ }^{156}$ se concluyó que los cuatro acusados, concejales de la Comisión de Gobierno, “....sabían cuáles eran sus obligaciones, pues en los asuntos de sus respectivas áreas, el procedimiento de aprobación era similar, y por tanto son coautores del delito contra la ordenación del territorio del art.320.2 CP que les imputaba el Ministerio Fiscal y otras acusaciones, al tomar parte directa y voluntaria en su ejecución." (FD $6^{\circ}$ in fine). En consecuencia, la Audiencia revocó el fallo absolutorio de la sentencia de instancia respecto a aquellos acusados y concluyó condenándolos como autores de una prevaricación urbanística del art.320.2 CP. Tras recurrir en las instancias pertinentes, ${ }^{157}$ los condenados, acudieron en amparo ante el TC español que, finalmente, inadmitió el recurso mediante Auto de 23 de enero de 2013. ${ }^{158}$ Pese a que los demandantes solicitaron la rectificación de aquel auto, el TC confirmó los motivos de la denegación del amparo constitucional. Por todo ello, finalmente, los demandantes acudieron al TEDH apelando posible vulneración del art.6.1 CEDH en la parte referida al derecho de toda persona a ser oída equitativamente por un Tribunal que decidirá “....sobre el fondo de cualquier acusación en materia penal dirigida a ella". En la STEDH se motivan claramente las razones, ante todo de índole procesal,

156 Concretamente que “...corresponde a los concejales recabar la información necesaria al objeto de estar lo suficientemente instruidos, teniendo en cuenta las decisiones de peso que se han de adoptar en el ámbito de dirección local"; y que "...no es posible ni es admisible que se amparen en una actuación automática y siguiendo las directrices de otros para votar favorablemente la concesión de una licencia..." (FD $6^{\circ}$ ).

157 Contra la SAP de Granada de 28 de julio de 2011, los condenados promovieron un incidente de nulidad de actuaciones, invocando el art.24.1 CE, denunciando la falta de audiencia pública en la apelación. Pero la AP de Granada denegó la solicitud de nulidad, por Auto de 30 de enero de 2012, al estimar que los principios de inmediación y contradicción, habían sido respetado en sede de apelación.

158 Según el TC no se vulneró la Constitución española y respecto a la queja relativa a la falta de audiencia en la apelación, entendió que los demandantes no lo habían planteado en el procedimiento previo, rechazándolo por no haberse agotado las vías de recursos internos. 
por las que finalmente se declara nula la sentencia del tribunal español que condenó a los demandantes. Ante todo el TEDH se aparta de la posición del TC español, porque entiende que "..no precisa cuales son las vías de recurso que los demandantes hubieran debido utilizar para plantear sus pretensiones.." ${ }^{159}$ En suma, el TEDH admitió a trámite la demanda (puntos 17 a 19) entrando a conocer sobre el fondo del asunto, en relación con la queja de los demandantes por haber sido condenados por la jurisdicción de apelación sobre la base de “...pruebas de carácter personal tales como la declaración de tres testigos, sin que se celebrara una audiencia pública." (punto 21)

El TEDH destaca la similitud de este caso con otras resoluciones precedentes, ${ }^{160}$ para centrar el problema del caso planteado en que la AP de Granada se pronunció - para llegar a una nueva interpretación jurídica de la actuación de los acusados-, "..sobre circunstancias subjetivas que les atañían, a saber su conciencia de la ilegalidad de la concesión de las licencias urbanísticas (...). Este elemento subjetivo ha sido decisivo en el establecimiento de la culpabilidad de los acusados. En efecto, el delito de corrupción urbanística exige que el acusado haya actuado de manera intencionada." A la vista de la resolución absolutoria del Juez de lo penal y de la condena de la Audiencia provincial, el TEDH declara que "...esta nueva valoración del elemento subjetivo del delito de corrupción urbanística se ha efectuado sin que los demandantes tuvieran la oportunidad de ser oídos personalmente para discutir, mediante un enjuiciamiento contradictorio, la nueva valoración efectuada por la Audiencia Provincial". En consecuencia, el

$159 \mathrm{Y}$ asimismo constata que los demandantes sí plantearon la correspondiente queja con respecto a la falta de inmediación, contra la SAP de Granada de 28 de julio de 2011 (punto 16).

160 Vid. sentencia Valbuena Redondo c. España, nº 21460/08, de 13 de diciembre de 2011) en los que se había entendido que, una audiencia se revela necesaria cuando la jurisdicción de apelación efectúa una nueva valoración de los hechos considerados probados en primera instancia y los reconsidera situándose de manera más allá de las consideraciones estrictamente de derecho (punto 24). 
TEDH no entra, en realidad, a cuestionar la concurrencia o no del elemento subjetivo del delito del art.320.2 CP en el caso en cuestión, sino que, específicamente, reprueba que “...la jurisdicción de apelación ha reinterpretado los hechos declarados probados y ha efectuado una nueva calificación de los mismos, sin respetar las exigencias del principio de inmediación".

Puede decirse que el TEDH admite la vulneración del art.6.1 CEDH por una cuestión procesal, pero sin desatender la importancia de dicho elemento subjetivo para constatar la culpabilidad del autor del delito del art.320.2 CP. A este respecto destaca que "..cuando la inferencia de un tribunal se refiere a elementos subjetivos (como, en este caso, la existencia de una intencionalidad), no es posible proceder a la valoración jurídica de la actuación de los acusados sin haber tratado previamente de probar la realidad de la misma, lo cual implica, necesariamente, la comprobación de la intención de los acusados con respecto a los hechos que se les imputan (punto $4^{\circ}$ Valoración TEDH). El TEDH concluye que, en el presente caso, la extensión del examen realizado por la Audiencia de Granada hacía preciso que los demandantes hubieran sido oídos en audiencia pública. Y por todo lo anterior, declara violado el art.6.1 del CEDH.

La trasposición de esta condena a nuestro país, se llevó a cabo por la STS de 24 de febrero de 2017, (Sala Segunda, Sección $1^{\text {a }}$; TOL 5984331). ${ }^{161}$ En resumen, y puesto que la STEDH de 8 de marzo de 2016 fue dictada tras la Ley 41/2015 de 5 de octubre (que, efectivamente entró en vigor el 16 de diciembre de 2015), se admite que la revisión solicitada por los entonces demandantes pueda tener efecto (al amparo de lo previsto en el art.954 apartado 3 LECRIM). Y, en consecuencia, el TS estimó el recurso de revisión y declaró la nulidad de la sentencia recurrida (FD $3^{\circ}$ ), esto es, anuló la SAP de Granada de 28 de julio de 2011 (Sección Primera, núm. 502/2011).

161 En ella se analiza la cuestión procesal sobre el efecto que ha de producir en nuestro derecho las sentencias del TEDH si el Estado español ha sido demandado y la demanda ha sido admitida (F.D. $2^{\circ}$ ). 
El iter procesal expuesto, tanto en la STEDH de 8 de marzo de 2016 como de la SAP de Granada de 28 de julio de 2011, pone de manifiesto que, en el fondo, la concurrencia del elemento subjetivo del tipo previsto en el art.320.2 CP se discute de manera instrumental. Con precisión la sentencia condenatoria dictada en sede de revisión por la AP de Granada, se anula por un defecto procesal que conculca el art.6.1 CEDH, al no concederse una audiencia a los condenados, donde hubiera habido inmediación del tribunal para analizar si efectivamente concurrió dicho elemento subjetivo. No puede aventurarse qué sentencia habría recaído si dicho derecho a la audiencia hubiera sido respetado, pero lo que parece evidente es que, entonces, dicha sentencia no habría vulnerado el art.6.1 CEDH. Por consiguiente, la condena del TEDH a nuestro país en la sentencia comentada pone de manifiesto la importancia del elemento especifico del conocimiento de la injusticia y la voluntad de cometerla, con respecto a la conducta típica de votar a favor de una resolución arbitraria del art. $320.2 \mathrm{CP}$. Ante todo, porque precisamente por la relevancia de dicho elemento subjetivo del tipo, según el Alto tribunal de Estrasburgo, no puede ser objeto de una reinterpretación, en una segunda instancia, sin conceder a los acusados el derecho a una audiencia, vinculado a la garantía constitucional de la presunción de inocencia.

Así las cosas, puede decirse que esta sentencia constituye un hito en la labor interpretativa y aplicativa de los elementos típicos de las prevaricaciones urbanísticas del art.320 CP, al enfatizar -como prácticamente ninguna otra resolución había hecho hasta entonces- la prueba del denominado elemento subjetivo del tipo. Y puesto que dicho elemento está presente en todos los delitos de los apartados $1^{\circ}$ y $2^{\circ}$ del art.320 CP, la doctrina del TEDH en esta materia, es aplicable a todos ellos. Más aún, podría incluso apuntarse que la comentada STEDH habrá de tenerse muy presente en relación con el resto de prevaricaciones específicas (art.322 y art.329 CP) puesto que también se construyen a partir de aquel elemento subjetivo. 


\section{Consecuencias jurídicas, prescripción y concursos}

La reforma penal operada por LO 5/2010, de 22 de junio, comportó un aumento de la pena de prisión de los dos apartados del art.320 CP, pues en el primero de ellos ahora se prevé una pena privativa de libertad de entre un año y seis meses a cuatro años. Cabe constatar un incremento considerable de esta pena $^{162}$ que, antes de dicha reforma, consistía en prisión de seis meses a dos años. Se aumenta así tanto del mínimo como del máximo de esta pena, de modo que será prácticamente imposible la aplicación retroactiva de esta reforma a favor del reo, por hechos cometidos antes de 2010. También será difícil acordar la suspensión de la ejecución de esta pena de prisión siendo, además muy complejo adoptar un acuerdo acerca de su sustitución. Por lo que toca a la pena de multa, no ha experimentado un cambio a raíz de la citada reforma LO 5/2010. Sin embargo, es importante retener que, a partir de dicha reforma, la multa pasa a preverse con carácter cumulativo con respecto a la de prisión y ya no alternativo, tal y como sucedía antes de 2010, con lo que, la reforma de dicho año, pretendió así evitar que funcionarios y responsables públicos, tuvieran un tratamiento privilegiado. ${ }^{163}$ A todo lo anterior, se sigue añadiendo la pena del art.404 CP, esto es, la inhabilitación especial para empleo o cargo público que -tras la LO 1/2015, de 30 de marzo- tiene una duración de nueve a quince años. Dicha pena habrá de referirse a los cargos y a la esfera administrativa en que se haya cometido el delito de prevaricación del art.320 CP. En este sentido, téngase en cuenta la STS de 1 de julio de 2011, FD $2^{\circ}$ (TOL2.174.537) donde se ratifica la condena por un delito de prevaricación urbanística del art.320. 2 CP y se destaca la obligación de determinar el alcance de la inhabilitación especial en relación con los parámetros establecidos en el art. $45 \mathrm{CP}$, de modo que ha de concretarse expresa y motivadamente en la sentencia.

162 Vid. VILLACAMPA ESTIARTE, C., "Delitos sobre la ordenación..." Op.cit.pág. 285.

163 Vid. Exposición de Motivos de la LO 5/2010, de 22 de junio (BOE N ${ }^{\circ} 152$, 23 de junio 2010) Punto XX, pág. 54819. 
Asimismo, conforme a la pena de prisión, cabe constatar un aumento del plazo de prescripción de los delitos del art.320.1 $\mathrm{CP}$ que sería de 5 años, conforme al art.131.1 CP, tras la entrada en vigor de la reforma penal de 2010. ${ }^{164}$ Este aumento de pena y plazo de prescripción también se aplicaría a los delitos del apartado $2^{\circ}$ art. $320 \mathrm{CP}$, por virtud de la remisión que, en dicho apartado, se contiene a la pena del apartado $1^{\circ}$.

Con respecto a los concursos, ha de tenerse muy presente que, junto a las modificaciones a los delitos del art.320 CP realizadas por la legislación penal de 2010, siguen siendo aplicables los delitos contra la Administración Pública en los términos reformados por la LO $1 / 2015$, que, a la postre y como seguidamente veremos, han resultado ser también determinantes a la hora de enjuiciar graves supuestos de tramas de corrupción urbanística. En especial los delitos de prevaricación genérica (art.404 CP), cohecho (arts. 419 a $427 \mathrm{CP}$ ), tráfico de influencias (arts. 428 a $431 \mathrm{CP}$ ) y malversación (arts. 432 a $435 \mathrm{CP}) .{ }^{165}$

A tal efecto, el caso "Malaya" es un ejemplo ilustrativo de la aplicación de una pluralidad de delitos relacionados con la corrupción. Como es sabido, dicho caso se enjuició en la SAP de Málaga $n^{\circ} 535 / 2013$, de 4 de octubre. A pesar de que los hechos allí enjuiciados ${ }^{166}$ fueron condenados conforme a diversos

164 Vid. MARTÍNEZ BUJÁN PÉREZ, C., Derecho penal Económico, 2015, Op.cit.pág. 927.

165 Además de los delitos enumerados supra, GONZÁLEZ CUSSAC, J.L. incluye, entre las figuras delictivas referidas a la corrupción, otros ilícitos menos aplicados, como los fraudes contractuales (art.436 CP), exacciones ilegales (art.437 CP), participación indebida del funcionario en negocios (art.439 CP) y ejercicio de actuaciones incompatibles (art.441 CP), vid. "El tratamiento en el Código penal de los tipos relacionados con la corrupción" Op.cit. págs. 6 a 16. La mayoría de estos delitos han sido reformados por la LO 1/2015, de 30 de marzo. Vid. VALEIJE ÁLVAREZ, "Cohecho" en GONZÁLEZ CUSSAC, J.L. (dir.) GÓRRIZ ROYO/MATALLÍN EVANGELIO (coords.) Comentarios a la Reforma del Código penal, $2^{\mathrm{a}}$ ed., Valencia, 2015, págs. 1159 y ss.

166 Se remontan al año 1998, siendo denunciados en 2005 por el jefe de los servicios jurídicos del ayuntamiento de Marbella quien acreditó múltiples 
delitos contra la Administración pública (en especial, cohechos y prevaricaciones genéricas), conviene sopesar si dicha condena no habría sido distinta si los hechos hubieran sucedido tras la reforma penal de 2010, pues algunos de aquellos hechos podrían haberse subsumido en los delitos del actual art.320 CP. ${ }^{167}$

La diversidad de delitos dirigidos a combatir la corrupción, hace que sea muy frecuente la aplicación de concursos entre, de un lado, alguno de los delitos del art.320 CP y, de otro, alguno de los delitos contra la Administración pública. Sin olvidar los concursos con otros delitos como, en especial, las falsedades (v.gr. falsedad de documento público cometido por funcionario art. 390.1,4 CP), habida cuenta de la importancia de la prueba documental en la fase probatoria del proceso penal en relación con los delitos del art.320 CP (vid. STS 14 de diciembre 2016, TOL5.916.784).

De especial relevancia a este respecto es la relación concursal que, por con frecuencia, puede plantearse entre alguno de los delitos del art.320 CP y el delito de prevaricación genérica del art.404 CP. ${ }^{168} \mathrm{~A}$ este respecto, hay que reparar en que, antes de la reforma del CP por LO 5/2010, la aplicación del art.320 $\mathrm{CP}$, en su apartado $1^{\circ} \mathrm{y}$-en especial- en el $2^{\circ}$, se veía dificulta-

irregularidades en el informe y en la concesión de licencias urbanísticas por parte de aquel ayuntamiento, además de otros ilícitos.

167 La aplicación del art. 320.1 CP a algunos hechos enjuiciados en aquella sentencia se reveló compleja, al no verificarse la conducta que -según la redacción originaria de este precepto en el CP de 1995- allí se tipifica; como también lo fue la aplicación del delito del apdo. $2^{\circ}$ del art.320 CP. Ante todo porque, antes de la reforma de LO 5/2010, se refería a la votación o aprobación -exclusivamente- de proyectos de edificación y concesión de licencias urbanísticas. De ahí que la mayoría de resoluciones administrativas arbitrarias fueran enjuiciadas desde la perspectiva de la prevaricación administrativa genérica del art. $404 \mathrm{CP}$. Vid. al respecto los hechos descritos en el FD genérico $16^{\mathrm{a}}$ de dicha sentencia.

$168 \mathrm{Vid}$. MANZANARES SAMANIEGO, J.L., en "Artículo $320 \mathrm{CP}$ ” en Comentarios al Código penal (tras las LLOO 1/2015, 30 de marzo y 2/2015, 30 de marzo), La ley-Wolters, Madrid, 2016, p. 1156. 
da, por el reducido número de instrumentos urbanísticos y actos administrativos que, a tenor del tipo allí previsto, podían informarse, votarse y resolverse. Quedaba, no obstante, la posibilidad de aplicar el delito del art.404 CP, confirmando así el carácter de delito genérico de éste, frente a aquella otra prevaricación más específica del ámbito urbanístico.

Pese a que el concurso de normas que se suscita entre los delitos de prevaricación específica del art.320 CP y el de prevaricación genérica art. $404 \mathrm{CP}$, parece evidente -al menos entre la doctrina penal-, la aplicación de las prevaricaciones urbanísticas plantea, en ocasiones, algunas dificultades para su delimitación con respecto a algunos delitos contra la Administración pública. ${ }^{169}$ Sea como fuere, a mi modo de ver, no cabe obviar que el art.320 CP sería el precepto especial (vid. así la STS núm. 1127/2009, Sala de lo Penal, Sección 1, de 27 noviembre, FD $6^{\circ}$ ) cuya aplicación preferente frente al art.404 CP (art.8.1 CP), viene obligada por el principio del legalidad penal. Dicha especialidad deriva, ante todo, de que los delitos del art.320 CP tutelan tanto el bien jurídico del art.404 CP como la "ordenación del territorio" y castiga particulares conductas de corrupción en el ámbito urbanístico, sancionando la autoría de concretas acciones que, de no existir este precepto, podrían enjuiciarse, a lo sumo, conforme a casos de participación -necesaria o no- o incluso quedar impunes. Desde esta perspectiva la aplicación del delito del art.320 CP desplazaría la calificación, en su caso, de los hechos como participación en un delito del art.404 CP; ;70 en concreto, de aquellas conductas consistentes en informar en contra de las normas urbanísticas, cualquiera de los instrumentos ahora previstos en el art.320.1 CP.

169 Sin ánimo de reproducir aquí una extensa discusión teórica, cabe apuntar que, en algunas sentencias, no siempre se repara en la relación de especialidad entre aquellos delitos (cfr. STS 25 noviembre 2009, FD $7^{\circ}$, TOL1.768.798, y STS no 497/2012 de 4 de junio).

170 Vid. MANZANARES SAMANIEGO, J.L., en “Artículo 320 CP” Op. y loc. ult.cit. 
Sentada la relación de especialidad que media entre el delito de prevaricación específica del art.320 CP y la prevaricación genérica del art.404 CP (vid. en este sentido también la Circular 7/2011 de la Fiscalía ${ }^{171}$ ), no se puede perder de vista la ampliación del ámbito típico que se ha producido en el art.320 CP, merced la reforma penal de LO 5/2010. Todo lo cual permite prever, a partir de la entrada en vigor de aquella reforma penal, un "recorte" en el ámbito típico del art.404 CP, con respecto a las conductas consistentes en la resolución de actos administrativos de carácter estrictamente urbanístico. Y ello porque ahora cabe subsumir en el art.320 CP aquellas actuaciones en relación no solo con licencias de obras sino también con instrumentos de planeamiento. Plantearían, no obstante, dificultades, la inclusión en el ámbito típico expreso del art.320 CP, de conductas relacionadas con actividades administrativas en que el riesgo de generar corrupción es muy alto: en especial, la contratación en materia urbanística y la firma de convenios, en este ámbito. Con todo, estos casos pueden -en mayor o menor medida-ser reconducidos a la figura genérica de prevaricación (art.404 CP). Así como también algunos otros ilícitos que no verifican la tipicidad de los delitos del art. $320 \mathrm{CP}$, como, por ejemplo, resolver, a sabiendas de su injusticia y arbitrariamente, en contra de la concesión de una licencia, proyecto o instrumento del planeamiento de los que se citan en el art.320 CP. O, por otro lado, cabría considerar el problema del acto de concesión de prórrogas de licencias urbanísticas, cuando éstas ya han sido concedidas y se verifican los requisitos de arbitrariedad e injusticia previstos en el art. $404 \mathrm{CP} .{ }^{172} \mathrm{Si}$ finalmente el castigo de alguno de estos ilícitos se realizara a través de una del art.404 CP, les correspondería una pena ${ }^{173}$ que sigue siendo más leve que la de cualquier prevaricación específica.

171 Circular 7/2011 sobre criterios para la unidad de actuación especializada del Ministerio Fiscal en material de Medio Ambiente y Urbanismo, pág. 1783

172 Se manifiesta a favor de ello MANZANARES SAMANIEGO, en Op. y loc. ult. cit.

173 Para una crítica a la pena de inhabilitación especial del art.404 CP en comparación con la gravedad de las previstas en la mayoría de delitos del 
Por otra parte, al margen de los delitos contra la Administración pública, ha de analizarse la situación en que, a resultas de la comisión de uno de los delitos del art.320 CP -en especial, el del apartado $2^{\circ}$, relativo a la concesión de una licencia, instrumento del planeamiento o proyecto-, efectivamente se llevan a cabo uno de los delitos del art.319 CP, pues aquí cabe plantear si se puede acudir al concurso de norma o al de delitos. En principio, el supuesto no parece de los más comunes en la práctica, pues implica que, por ejemplo, un mismo sujeto -funcionario o autoridad- que vota o resuelve a favor de una licencia urbanística manifiestamente ilegal, a sabiendas de su injusticia, asimismo, se beneficia de la misma porque, por ejemplo, se concede a una empresa constructora de su titularidad pero dirigida por un testaferro, para cometer un delito del apartado $1^{\circ}$ art. $319 \mathrm{CP}$, o recae a favor de un familiar con el que acordó llevar a cabo un delito del art. 319.2 CP. Pese a que el supuesto parece complejo, un caso similar ya ha sido sentenciado por la STS de 21 de febrero de 2018 (número 88/2018, TOL6.519.936). ${ }^{174}$

Título XIX del Código penal, vid. JAREÑO LEAL, A., en Corrupción y delincuencia de los funcionarios en la contratación pública, Iustel, Madrid, 2011 pág. 64.

174 En la misma, se resuelve el recurso de casación planteado contra la sentencia dictada por la Audiencia Provincial de Valencia (Sección segunda) de 23 de enero de 2017. En ésta se condenó a uno de los acusados C.O. -administrador y socio único de una empresa constructora TSLU-, como autor de un delito continuado contra la ordenación del territorio. Asimismo, se condenó al padre del anterior, A. U., alcalde de una localidad valenciana desde el año 1979, en concepto de cooperador necesario de un delito continuado contra la ordenación del territorio, así como en concepto de autor de un delito continuado de prevaricación urbanística. Los hechos por los que se les condenó en primera instancia tuvieron lugar los años 2003 y 2004, cuando uno de los condenados fue elegido alcalde del municipio valenciano, vendiendo en ese momento las participaciones sociales de la empresa que dirigía -TSLU-, a su hijo. Los hechos de la sentencia se apoyan en un acuerdo entre el padre y el hijo para construir -a través de aquella entidad-, viviendas en diversos polígonos del término municipal, en terrenos que tenían la calificación de suelo no urbanizable común, en parcelas inferiores a diez mil metros cuadrados, amparadas en licencias otorgadas, unánimemente, por el Pleno municipal del Ayuntamiento, tras 
Para algunos autores la aplicación en este caso de un concurso de delitos entre el art. 319 y art.320 CP vulneraría el principio de ne bis in idem, más aún teniendo en cuenta el incremento punitivo que ha experimentado el art. $320 \mathrm{CP} .{ }^{175}$ No obstante, este último precepto prevé un delito pluriofensivo, toda vez que, formalmente, el art. $320 \mathrm{CP}$ no alude al art. $319 \mathrm{CP}$ como posible "delito-fin" de las prevaricaciones urbanísticas, ni éstas han de aplicarse solo en el caso en que, posteriormente, se consuma uno de los delitos del art. 319 CP. Porque la efectiva emisión de una licencia urbanística, proyecto o instrumento del planeamiento ilegal, no es el resultado típico del delito del art.320 CP, ni tampoco lo es, la efectiva iniciación de las respectivas obras amparadas en aquellas licencias, proyectos o instrumentos ilegales, que, en su caso, podrán reconducirse al art. 319 CP o a las correspondientes infracciones administrativas. De modo que, aún habiéndose concedido, con arbitrariedad y a sabiendas, una licencia ilegal y sin empezar a llevar a cabo obras a su amparo, se habrá consumado la prevaricación urbanística. En suma, los ilícitos típicos de los delitos de los arts. 319 y 320 $\mathrm{CP}$ son independientes y no se implican en todo caso. Por todo ello, no parece que solución del concurso aparente de normas entre los correspondientes delitos del art. $319 \mathrm{y}$ del art. $320 \mathrm{CP}$, sea la más satisfactoria, pudiendo optarse por un concurso de delitos,${ }^{176}$ sin vulnerar el principio ne bis in ídem. ${ }^{177}$

Decreto provisional con visto bueno del citado alcalde. No obstante, éste era conocedor de que el arquitecto técnico municipal tenía reparos sobre la legalidad de las obras. Pese a ello, se ejecutaron 25 edificaciones en diversas parcelas de aquellos polígonos.

175 Vid. MARTÍNEZ-BUJÁN PÉREZ, Derecho penal económico... $5^{\text {a }}$ ed.,Op. cit. pág.927.

176 Pueden, barajarse, alternativas que impliquen un concurso de delitos entre el art. $404 \mathrm{CP}$ y el correspondiente delito del art.319 CP o bien, acudir al concurso de delitos entre determinado delito del art. $320 \mathrm{y}$ del art. 319 CP.

177 La vulneración de este principio fue alegada por el alcalde condenado y recurrente en la STS de 21 de febrero de 2018, porque entendía que se debía haber aplicado la regla de consunción del art.8.3 CP, de modo que el desvalor de la cooperación en el delito urbanístico art. 319.2 CP debió consumirse 
En otro orden de cosas, ha de tenerse en cuenta, por último, que, respecto a los delitos del art.320 CP, se admite, en sede judicial, la continuidad delictiva conforme al art.74.1 CP (vid., entre otras, la STS de 7 de julio de 2014, FFDD $1^{\circ}$ y $2^{\circ}$, TOL4.443.383; STS 21 de febrero de 2018, FD Preliminar, TOL6.519.936).

\section{Conclusiones}

1.- En primer lugar, ha de destacarse que el ámbito más frecuente donde, desde finales del s. XX, se fraguaron en nuestro país los procesos de corrupción en urbanismo ha sido el local, al amparo de administraciones municipales que, en determinados casos, han mantenido una actitud tolerante cuando no abiertamente colaboradora respecto a la comisión de infracciones y delitos urbanísticos. Aquella actitud puede explicarse por cuanto la explotación a toda costa del suelo, se reveló como una actividad enormemente lucrativa, toda vez que la insuficiencia crónica de determinados municipios, a la hora de encontrar medios de financiación, pudo acelerar el proceso de explotación irracional del suelo. Entre otras características de dichas entidades locales, puede destacarse que las tramas de corrupción se han

en el propio de la prevaricación específica (art.320.2 CP) "necesariamente dirigida a tal fin". El TS, no obstante, sostiene que media un concurso delictivo, basándose en anteriores sentencias (vid. STS 12/2009, de 27 de noviembre) donde ya se indicaba que la aplicación del art. 320 junto al 319 , no conculca el principio non bis in ídem, “...pues no cabe desconocer que el bien tutelado con la sanción penal en la prevaricación administrativa no es sólo la ordenación del territorio sino también la administración pública, como en toda prevaricación administrativa (...)". Según TS, el recurrente obvia que ambos condenados se pusieron de acuerdo para construir. De modo que concluye que ninguno de los dos delitos por los que fue condenado lleva por sí la acción ni el desvalor del otro. En definitiva, el TS desestima el motivo del recurrente, llegando a la conclusión de que “...no existe un concurso de normas sino de delitos, sin que ninguno de ellos sea medio necesario para la comisión del otro, por lo que concurren en modalidad real" $\left(\mathrm{FD} 2^{\circ}\right.$ ). 
cebado, normalmente, en municipios con un sector turístico en alza que, por ello mismo, tenían más proyección internacional, en especial, aquellos ubicados en las costas o zona maritimoterrestre de nuestro país.

2.- Por otra parte, desde el punto de vista criminológico, los agentes involucrados en los procesos de corrupción urbanística han sido, en el ámbito del personal al servicio de la Administración, ante todo autoridades, concretamente, concejales y alcaldes, y personal de confianza de aquéllos, así como empleados públicos con competencias para informar o inspeccionar. Más aún, a la vista de recientes casos, los autores principales de las tramas de corrupción en urbanismo, vienen siendo aquéllos que, a su respectiva condición de particulares o funcionarios, aúnan un cargo político de modo que, por lo general, son considerados autoridades (ex. art.24.1 CP). Ello reafirma la conclusión relativa a que la clase de corrupción desarrollada en el ámbito urbanístico es, ante todo, de índole política y no tanto administrativa.

3.- En particular, en el ámbito urbanístico se ha manifestado una clase de corrupción específica que, inicialmente, podría enjuiciarse desde la óptica de delitos genéricos contra la Administración pública (v.gr. prevaricación, cohecho, malversación y tráfico de influencias). Pero también desde los delitos especificos de prevaricación introducidos en el art.320 CP que son ley especial, al menos respecto de la prevaricación genérica del art.404 CP. Sin embargo, el recurso a la creación de tipos penales especificos en materia urbanistica no ha sido la solución mágica, ni para los complejos problemas que rodean a este sector de la actividad administrativa, ni para el desorden urbanistico al que aún asistimos en nuestros dias. A tal efecto algunas carencias de los delitos del art. $320 \mathrm{CP}$ se pudieron enmendar en la reforma penal acometida por LO 5/2010, de 22 de junio, si bien aún puede hablarse de ciertos déficits respecto a estos delitos, habida cuenta de su moderada aplicación práctica ante nuestros tribunales. 
4.- A este respecto, la investigación aquí desarrollada ha tratado de señalar concretos problemas legislativos no resueltos, a tener en cuenta de cara a posibles reformas penales. Uno de dichos problemas consistiría en haber dejado fuera del ámbito típico de los delitos del art. $320 \mathrm{CP}$, cualquier referencia a la contratación y a los convenios que arbitrariamente se pueden acordar o conceder en materia urbanística, ámbitos que, como la realidad criminológica demuestra, suelen ser origen de las tramas corruptas que mayores perjuicios económicos causan a los intereses generales. A tal efecto, habría que sopesar la posibilidad de dotar de mayor ámbito de aplicación al delito del art.320.2 CP, previendo conductas relativas a votar o resolver arbitrariamente a favor de aprobar convenios que pudieran alterar instrumentos y planes urbanísticos, a sabiendas de su injusticia. Unido a lo anterior, habría que considerar la previsión de concretas actuaciones, como, por ejemplo, cuando, a sabiendas, se vota o resuelve arbitrariamente a favor de la revisión de los instrumentos del planeamiento y no solo cuando se aprueban éstos y los restantes instrumentos allí previstos.

5.- Otra de las cuestiones legislativas que cabría abordar es la relativa al reenvío normativo que se prevé en el art. 320.1 CP y que también afecta a los delitos de su apartado 2. Sería conveniente que el precepto requiriera una contravención, cuanto menos, grave o muy grave de las normas urbanisticas vigentes y de ordenación territorial. De este modo se excluiría, sin duda alguna, el castigo de infracciones leves de dichas normas, en los términos que, posibilita la referencia a "manifiestamente ilegales" del art. 329.1 CP. Es cierto que, de facto, al integrar el reenvío con la normativa administrativa, las infracciones leves, por lo general, quedarán excluidas pues, en muchos casos, no se "informan" sino que se someten al novedoso régimen de las comunicaciones previas. A ello se une que la exigencia de "arbitrariedad" de toda prevaricación también ha de predicarse de las urbanísticas y, por tanto, solo podrían castigarse contravenciones muy graves. No obstante, constatada la dinamicidad de la legislación administrativa urbanística, se ajustaría mejor al 
principio de legalidad, la exigencia expresa en el art.320 CP de una infracción grave o muy grave de aquellas normas urbanísticas y de ordenación del territorio, que no impediría la aplicación de estas prevaricaciones en casos de que dicho ilícito, eventualmente, constituyera un delito urbanístico.

6.- Al propio tiempo, sería preciso exigir que el tipo del art. 320.1 CP previera alguna restricción a la modalidad de conducta consistente en omitir la realización de inspecciones obligatorias, en el sentido de que debiera ser delictiva solo si la inspección omitida permitiera directamente la comisión de infracciones urbanísticas, cuanto menos, graves o, directamente, muy graves. Para ello podría, por ejemplo, requerirse cierta gravedad en la omisión, en el sentido que inequívocamente fuera a dar pie a la comisión de infracciones urbanísticas, al menos, catalogadas conforme a aquella gravidad.

7- Pese a que todas estas propuestas van dirigidas a introducir mejoras en el art.320 CP, ha de concluirse descartando una excesiva confianza en que los delitos allí previstos puedan, por sí solos, acabar con los graves problemas de corrupción urbanística en nuestro país. Ahora bien, dichas propuestas sí pueden servir para luchar más eficazmente contra los ilícitos vinculados a dicha corrupción que, además, como demanda el postulado de ultima ratio, posean relevancia necesitada, merecedora y susceptible de sanción penal.

\section{Bibliografía}

ACALE SÁNCHEZ, M.: "Tratamiento de la corrupción urbanística en el Proyecto de Ley Orgánica de reforma del Código penal de 15 de enero de 2007”, en La Ley Penal. Revista de Derecho penal, Procesal y Penitenciario, núm.38, año IV, mayo, 2007.

- Delitos urbanísticos, Barcelona, 1997.

- Los nuevos delitos sobre la ordenación del territorio y el urbanismo: adaptado a la LO 5-2010 de modificación del Código penal, Barcelona, 2011. 
AMENÓS ALAMO, J., La inspección urbanistica: concepto y régimen jurídico. Barcelona, 1999.

BERMEJO VERA, J., "La administración inspectora", El Derecho administrativo en el umbral del s.XXI, tomo I, Valencia, 2000.

BOIX REIG, J., "Urbanismo y Derecho penal" en Diccionario de Derecho penal económico, $2^{\mathrm{a}}$ ed., (Dir.: Boix Reig; Coord.: Lloria García), Madrid, 2017.

BOLDOVA PASAMAR, M.A., Los delitos urbanisticos, Barcelona, 2007.

CARMONA SALGADO, C., en Curso de Derecho Penal Español. Parte Especial, II (dir. COBO DEL ROSAL, M.), Madrid, 1997

COBO DEL ROSAL, M.:

"Examen crítico del párrafo $3^{\circ}$ del artículo 119 del Código penal español" en Revista General de Legislación y Jurisprudencia, $\mathrm{n}^{\circ} 212,1962$

- /QUINTANAR DÍEZ, "Comentario al art. 24 CP", en Comentarios al Código Penal. Tomo III. Artículos 24 a 94, (dir. Cobo del Rosal), Madrid 2000.

DE LA MATA BARRANCO, N.:

- $\quad$ "El art.320.1 C.P.: prevaricación específica en caso de informes favorables a proyectos de edificación o concesión de licencias contrarias a las normas urbanísticas", en Delitos contra el urbanismo y la ordenación del territorio, (ed. DE LA MATA BARRANCO, N.) Oñate, 1998.

- "El funcionario público ante el Derecho penal: cuestiones generales" en Revista jurídica de Castilla y León. n. ${ }^{\circ}$ 20. enero 2010.

DE VICENTE MARTÍNEZ, R., "La responsabilidad penal del funcionario público o autoridad en materia de ordenación del territorio", Sanción penal y sanción administrativa en materia de ordenación del territorio, (coord. TERRADILLOS BASOCO, J. M.), Cádiz, 1997.

DÍAZ Y GARCÍA CONLLEDO, M., voz “Autoridad y funcionario a efectos penales" en Enciclopedia jurídica básica, vol. I, Madrid, 1995. 
GÓMEZ TOMILLO, M.: “Artículo 320” Comentarios prácticos al Código penal, t. IV, $1^{\mathrm{a}}$ ed., Pamplona, 2015.

- “Artículo 320”, Comentarios al Código penal, $2^{a}$ ed., Lex Nova, 2011

- Urbanismo, Función pública y Derecho penal, Granada, 2000.

GÓMEZ RIVERO, M.C., "Ilegalidad urbanística: acerca de los límites entre el injusto penal y las infracciones administrativas" en Revista Electrónica de Ciencia Penal y Criminología, 19-25 (2017).

GONZÁLEZ CUSSAC, J.L.: El delito de prevaricación de autoridades y funcionarios públicos (2a ed.), Valencia, 1997.

- "Prólogo" a Los delitos de prevaricación urbanística, GÓRRIZ ROYO, E., Valencia, 2004.

- "El tratamiento en el Código penal de los tipos relacionados con la corrupción. Balance crítico" en La corrupción en la gestión política, cursos de formación CGPJ, 2013.

GÓRRIZ ROYO, E.: Protección penal de la Ordenación del Territorio. Los delitos contra la ordenación del territorio en sentido estricto del art.319 CP, Valencia, 2003, págs. 149 a 157.

- "Los delitos sobre la ordenación del territorio" en Comentarios a la reforma penal de 2010 (dirs. ÁLVAREZ GARCIA, J./GONZÁLEZ CUSSAC, J.L.), Valencia, 2010.

- "Omisión y tolerancia administrativa en el derecho penal del medio ambiente, a propósito del art.329.1. $2^{\mathrm{a}} \mathrm{CP}$ ” en Revista de Derecho y Proceso penal, año 2005-2, nº 14.

- $\quad$ "Demolición, reposición, responsabilidad civil y comiso en los delitos sobre la Ordenación del territorio: el apdo. $3^{\circ}$ art.319 CP (conforme a la LO 5/2010, de 22 de junio)" en Estudios penales y Criminológicos, vol. XXX, 2010.

- $\quad$ "Prevaricaciones específicas en Medio Ambiente y Ordenación del Territorio, y técnicas autorizatorias: posibles cambios a raíz de la directiva de servicios", en, Prestación de servicios, administraciones públicas y Derecho 
administrativo. Especial referencia al medio ambiente (dirs. CASADO/FUENTES/GIFREU), Valencia, 2013.

JAREÑO LEAL, A.: Corrupción y delincuencia de los funcionarios en la contratación pública, Iustel, Madrid, 2011.

- "La corrupción en la contratación pública" en Corrupción pública: cuestiones de Política Criminal (I), Jareño Leal (dir.), $1^{\text {a }}$ ed., 2014

JAVATO MARTÍN, A.M., "El concepto de funcionario y autoridad a efectos penales" en Revista Jurídica de Castilla y León. n. ${ }^{\circ}$ 23. Enero, 2011.

MANZANARES SAMANIEGO, J.L., "Artículo 320 CP” en Comentarios al Código penal (tras las leyes orgánicas $1 / 2015$, de 30 de marzo y 2/2015, de 30 de marzo), La ley-Wolters, Madrid, 2016.

MARTÍN PARDO, A., Los daños sociales derivados del delito urbanístico, Valencia, 2017.

MARTÍNEZ BUJÁN PÉREZ, C., Derecho penal Económico y de la empresa, $5^{\text {a }}$ ed., Valencia, 2015.

MUÑOZ CONDE, F.: Derecho Penal. Parte Especial, 14 ${ }^{\mathrm{a}}$ Ed., Valencia, 2002.

- Derecho penal. Parte Especial, 20ª ed., Valencia, 2015

OCTAVIO DE TOLEDO, E., La prevaricación de funcionario público, Madrid.

OLAIZOLA NOGALES, I., «Concepto de funcionario público a efectos penales», en Delitos contra la Administración Pública, (coord. Asúa Batarrita), Oñati, 1997.

ORTS BERENGUER, E., "Comentarios al art.24" en VIVES ANTÓN, T.S. (coord.), Comentarios al Código penal de 1995, vol. I, 1996.

PAREJO ALFONSO, L. "La ordenación territorial y urbanística en el contexto del a política económica y social del Estado" en Documentación Administrativa, no 271-272, (enero-agosto 2005).

POMARES CINTAS, E./BERMEJO CHAMORRO, A.J., “¿Era necesario reformar los delitos urbanísticos? Especial referencia a los delitos de corrupción urbanística y a su 
trayectoria jurisprudencial", en UNED, Revista de Derecho penal y Criminología, $3^{\mathrm{a}}$ Época, $\mathrm{n}^{\circ}$ 6, 2011.

POZUELO PÉREZ, L.: /DOPICO GÓMEZ-ALLER, J., en “Demolición o comiso" Diario La Ley, 19 de mayo de 2008

- "La respuesta penal a la delincuencia urbanística" en "Urbanismo y corrupción" Anuario de la Facultad de Derecho de la Universidad Autónoma de Madrid, 12 (2008).

QUINTERO OLIVARES, G., "Observaciones sobre la parte especial del Anteproyecto de Código Penal. Delitos contra la vida, libertad y contra el patrimonio y el orden económico", en La reforma del Derecho penal, en MIR PUIG, S. (ed.), Bellaterra, 1980.

RAMON RIBAS, E., "La derogación jurisprudencial del art.24.2 $\mathrm{CP}$ (concepto de funcionario público)", en Estudios Penales y Criminológicos, vol. XXXIV (2014).

REBOLLO PUIG, M., "La actividad inspectora" en La función inspectora, INAP, Madrid, 2013.

RODRIGUEZ RAMOS, L., "La protección penal del urbanismo (Pautas para criminalizar algunas conductas)" en Revista de Derecho Urbanístico, 1983.

ROMEO CASABONA, C./SOLA RECHE, E./BOLDOVA PASAMAR, M.A. (coords.) en Derecho penal. Parte Especial. Conforme a las Leyes Orgánicas 1 y 2/2015, de 30 de marzo, Granada, 2016.

SANTANA VEGA, D., en "Artículo 320" en Comentarios al Código penal. Reforma LO 1/2105 y LO 2/2015, (dirs. CORCOY BIDASOLO, M./MIR PUIG, S.) Valencia, 2015.

SILVA SÁNCHEZ, J.M., “¿Política penal moderna? Consideraciones a partir del ejemplo de los delitos urbanísticos en el nuevo Código penal", Actualidad penal, n²3, 1998.

TERRADILLOS BASOCO, J., "Responsabilidad del funcionario público en delitos relativos a la ordenación del territorio y la protección penal del patrimonio histórico y del medio ambiente" en Estudios penales y criminológicos XX, Santiago de Compostela, 1997. 
VALEIJE ÁLVAREZ, I.: "Reflexiones sobre los conceptos penales de funcionario público, función pública y "personas que desempeñen una función pública", C.P.C., $\mathrm{n}^{\circ}$ 62, 1997, págs. 435 a 507.

- "Cohecho" en GONZÁlEZ CUSSAC, J.L. (dir.) GÓRRIZ ROYO/MATALLÍN EVANGELIO (coords.) Comentarios a la Reforma del Código penal, $2^{\mathrm{a}}$ ed., Valencia, 2015.

VERCHER NOGUERA, A.: La delincuencia urbanistica. Aspectos penales prácticos sobre urbanismo y ordenación del territorio. Madrid, 2002.

- $\quad$ "La corrupción urbanística. Una nueva expresión delictiva", en Claves de la razón práctica, nº 139, 2004.

- "El esquema y estructura de la nueva especialidad de urbanismo y medio ambiente en el seno del Ministerio público", en La ley penal, $\mathrm{n}^{\circ} 38$, Año IV, mayo 2007.

VILLACAMPA ESTIARTE, C.: "La accesoriedad del Derecho penal frente al Derecho administrativo: criterios de imputación penal en el delito urbanístico" en Studia Iuridica, año $2008, n^{\circ} 23$ (Dedicado a la normativa urbanística desde la perspectiva administrativa y penal).

- "Delitos sobre la ordenación del territorio y el urbanismo (arts. 319 y $320 \mathrm{CP}$ )" en La Reforma Penal: análisis y comentarios (dir. QUINTERO OLIVARES, G.,) Cizur Menor, 2010.

VILLORIA MENDIETA, M.: /JIMÉNEZ SÁNCHEZ, F., «La corrupción en España (2004-2010): datos, percepción y efectos», Revista Española de Investigaciones Sociológicas, 138, abril-junio, 2012.

- CCorrupción pública" Eunomía. Revista en Cultura de la Legalidad No 5, septiembre 2013 - febrero 2014.

VVAA Una regulación alternativa contra la corrupción urbanística y otras conductas delictivas relacionadas. Grupo de Estudios de Política Criminal, 2010. 
www.sincicdegreuges.gva.es/informes: Informe a las Cortes Valencianas 2006. Sindic de Greuges de la Comunitat Valenciana (Dña. Emilia Caballero Álvarez).

www.defensordelpueblo.es: Defensor del pueblo. Informe anual 2002 y debate de las Cortes Generales (en informes y documentos). 